\title{
رؤية جمالية لإثراء ملابس السيدات \\ باستخدام أسلوب التطريز بالاسموكينج
}

\author{
إعداد \\ د/ امحمد جابر السيد محمد \\ استاذ مساعد بقسم تصميم الازياء

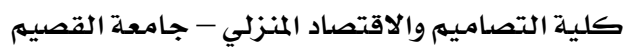

مجلة بحوث التربية النوعية ـ جامعة المنصورة

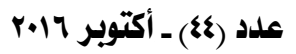




\section{روئية جمالية لإثراء ملابس السيدات}

\section{باستخدام أسلوب التطريز بالاسموكينج}

إعداد

* أ محمد جابر السيد محمد

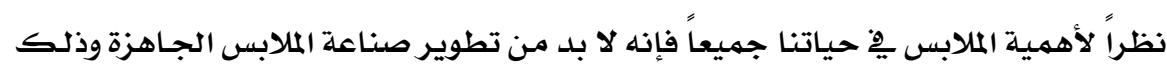

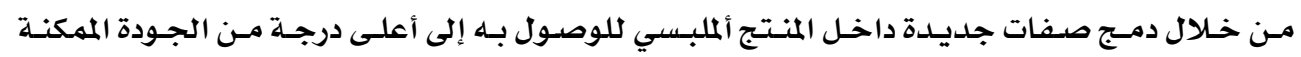

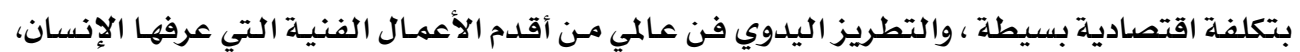

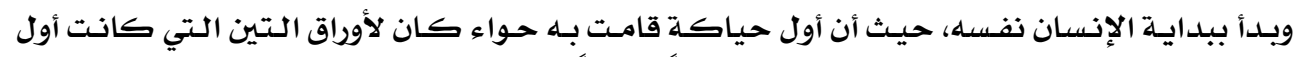

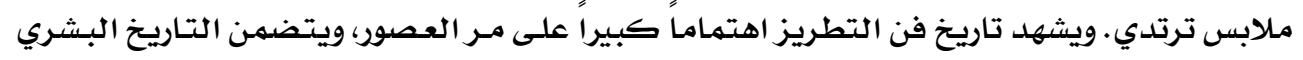

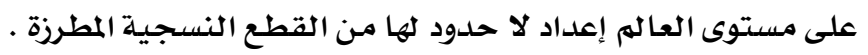

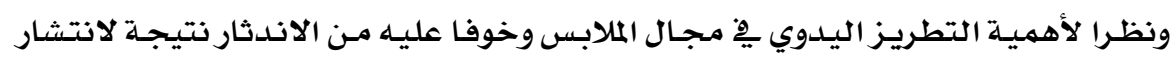

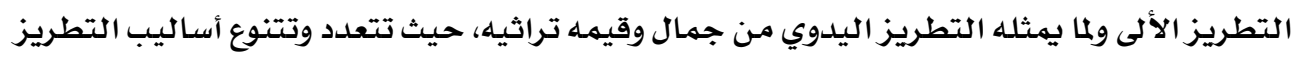

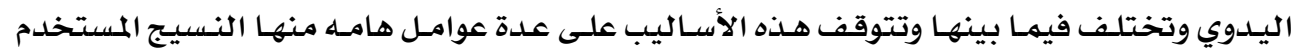

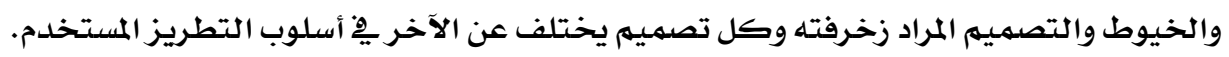

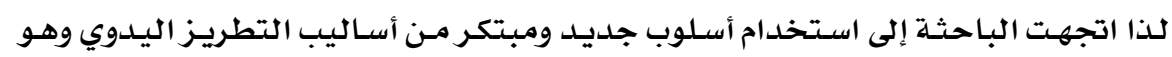

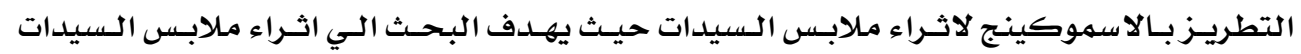

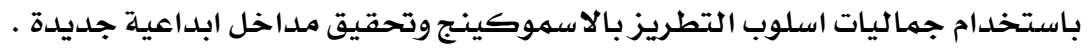

يظهر تصميه الموضدة وتنوعه وتطوره كمؤثر حضاري، من واقع خصائصها المنفردة، وتطراً

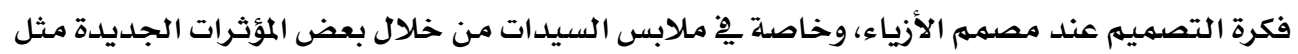

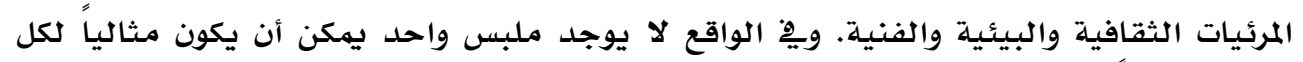

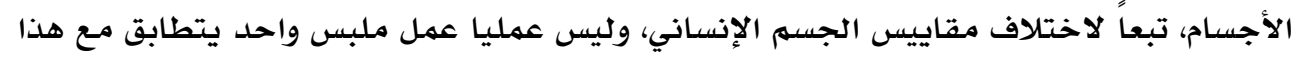

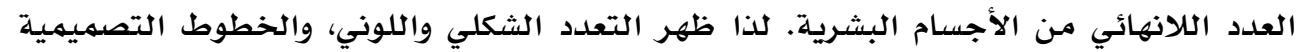

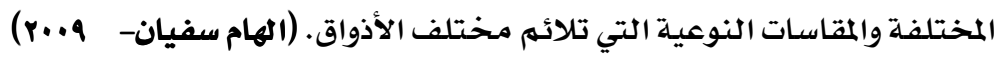


ويعـد التطريـز الركيـزة الأسـاسية للكشف عن الملامسح المختلفـة لبقيـة الفنـون، لما يشتمل

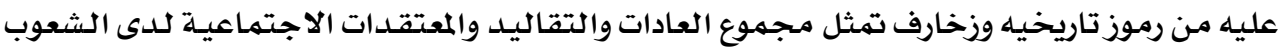

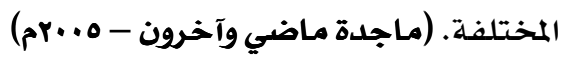

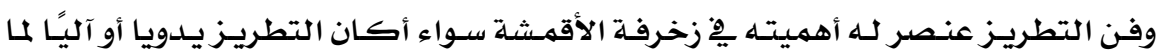

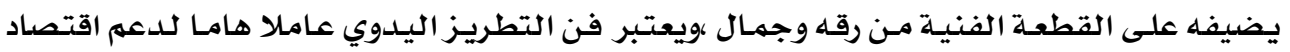

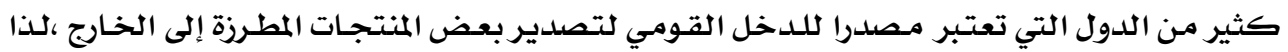

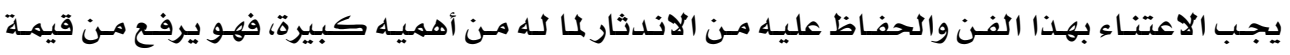

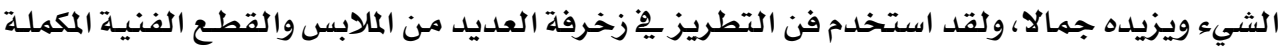

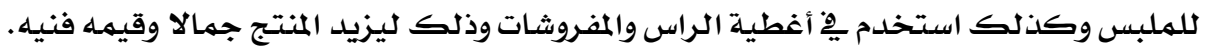

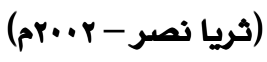

وعمليـة التطريزز هـى احسدى المصادر الرئيسيسية لاعطـاء تـأثيرات وملامس مختلفــة لسطح

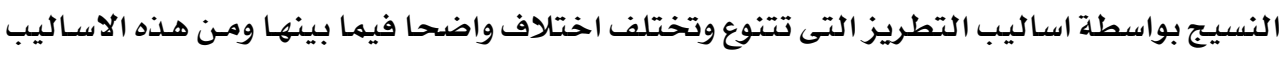

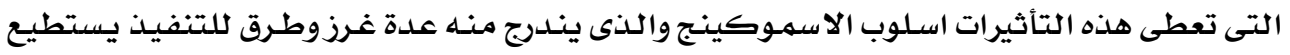

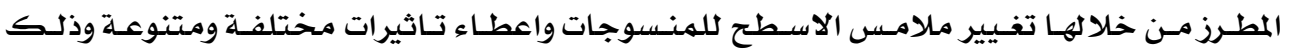

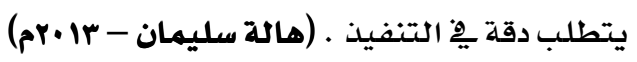

وقد تعرضت الباحثة إلى الدراسات السابقة التي لها اتصال مباشر أو غير مباشـر بموضـوع الدراسة الحالية وهي:

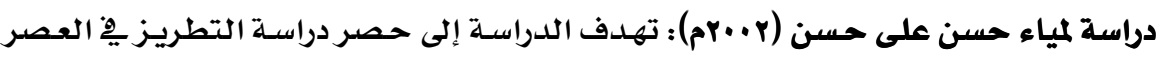

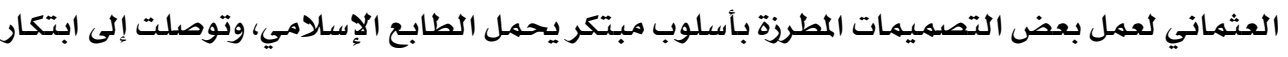

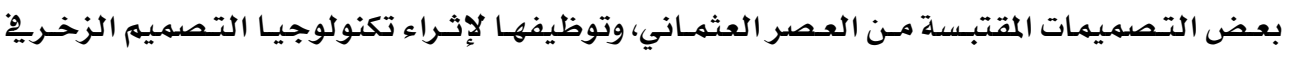

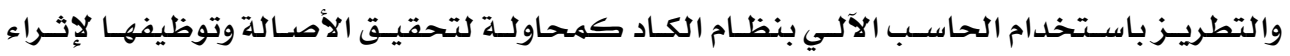
التصميم الزخريف وتكنولوجيا التطريز الآلي.

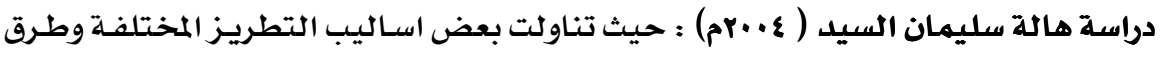

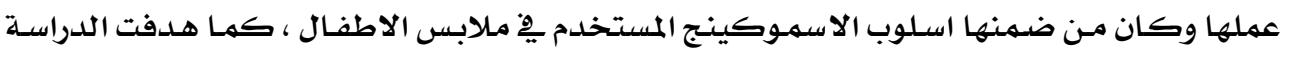

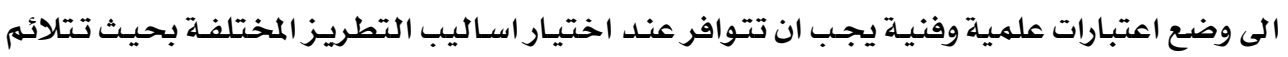

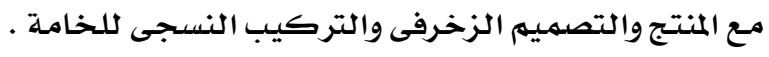

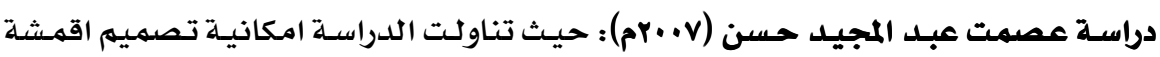

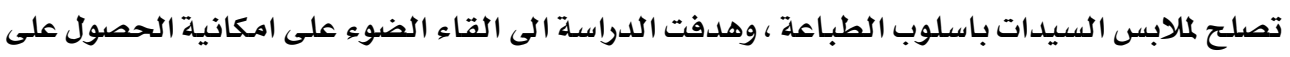

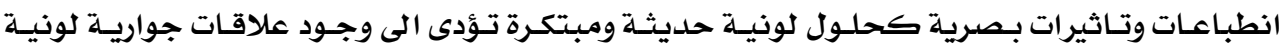

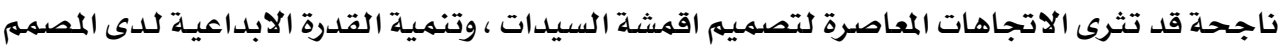

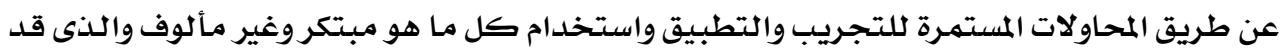
يؤدى الى نتائج مدهشة ونس وغير متوقعـة . 


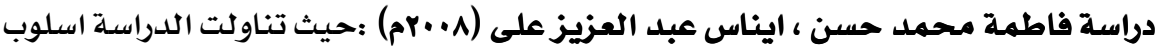

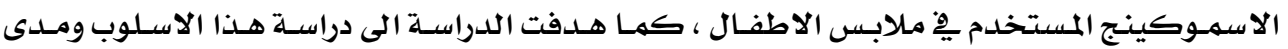

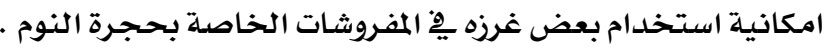

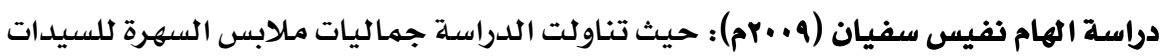

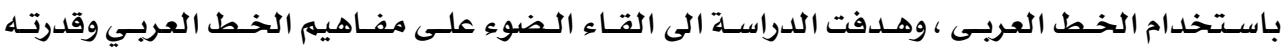

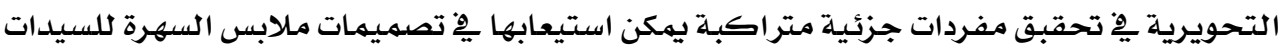

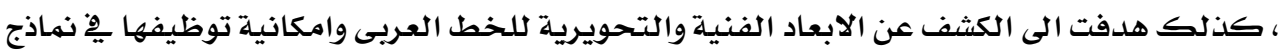

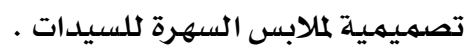

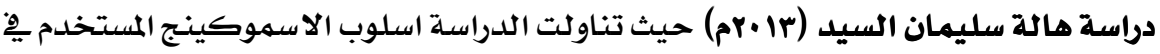

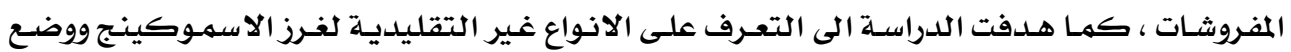

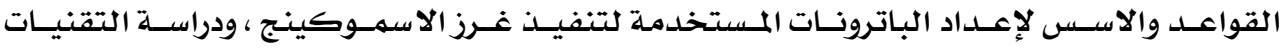

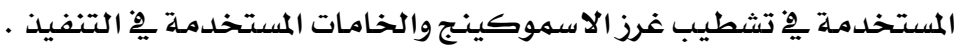

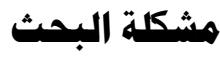

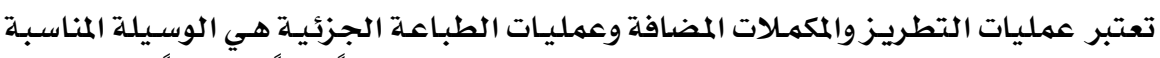

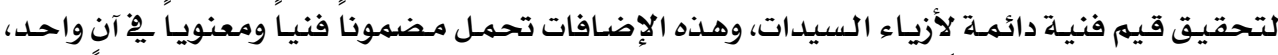

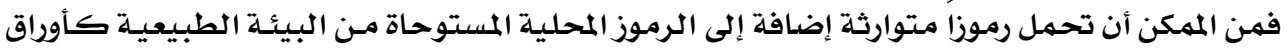

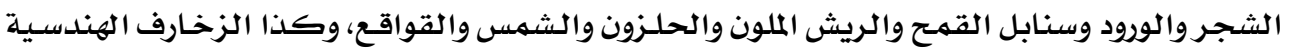

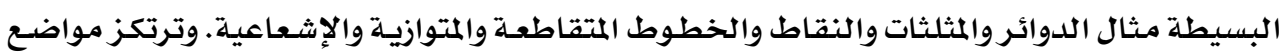

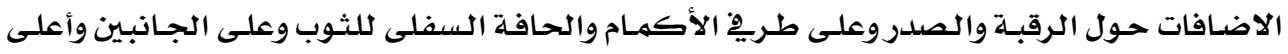

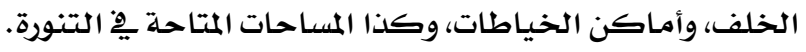

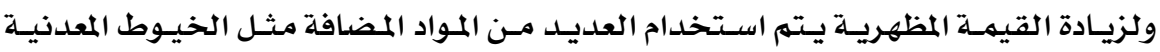

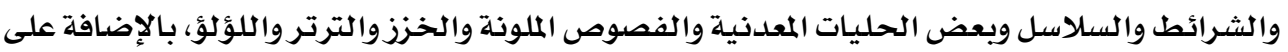

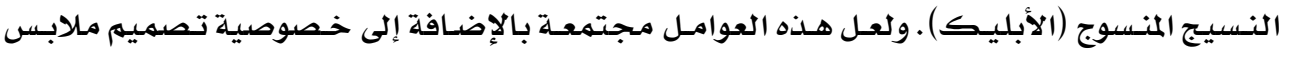

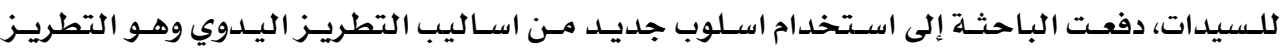

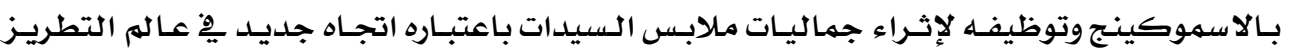

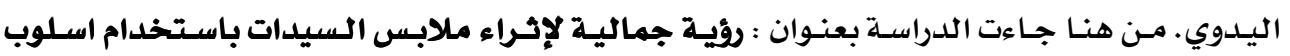

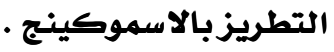
فالتطريز بالاسموكينج قيمة جمالية مضافة وابداعات فنية تتطلب الكشف عنها والإفادة

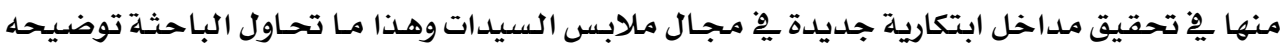

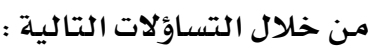
ا ـ هل يمكن إثراء مـلابس السيدات باستخدام جماليـات أسلوب التطريز بـالاسموكينج وتحقيق 
r. ما الاسس الفنية والعلمية المتبعة عند تنفيذ اسلوب التطريز بالاسموكينج ؟

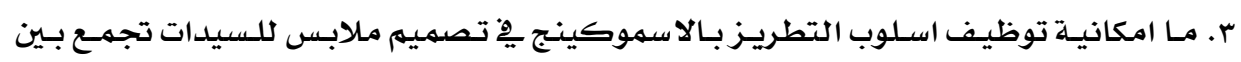

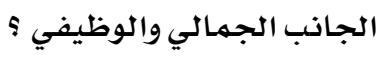

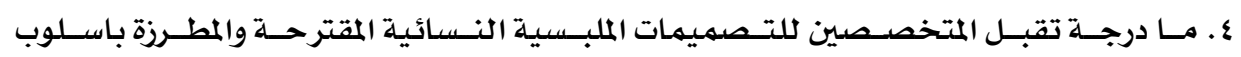

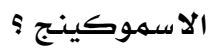
هدف البمث : (1)

ا ـ اثراء ملابس السيدات باسـتخدام جماليـات اسـلوب التطريـز بـالاسموكينج وتحقيـق مـداخل

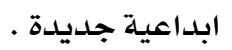

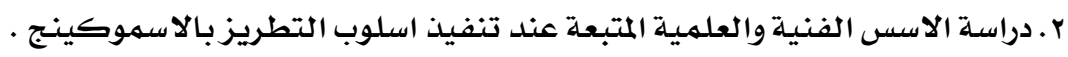

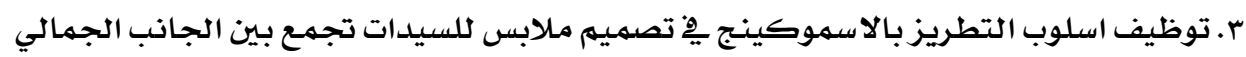

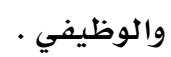

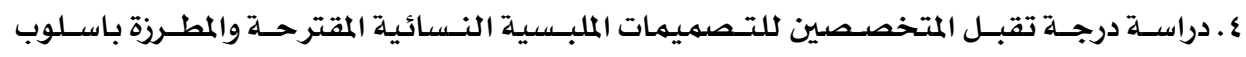
الاسموكينج

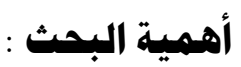

ا ـ تنمية القدرة الابداعية لدي المصمهم من خلال استخدام كل ما هو جديد وغير مـألوف والدي

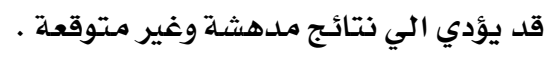

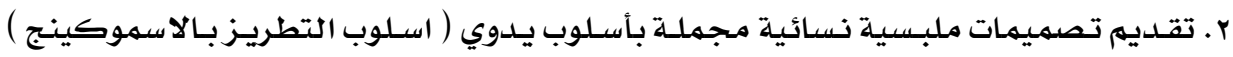

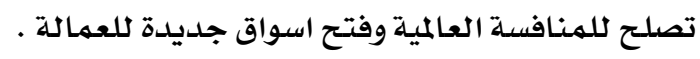

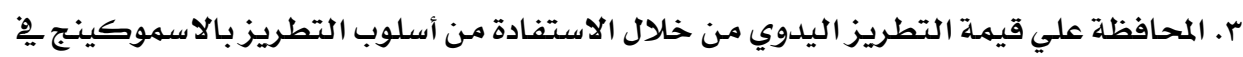

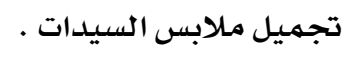

ع . سد متطلبات السوق المتغيرة والمستمرة يِّ الحاجة الي تقديم كل مل ما هو جديد وجذاب وخاصـة

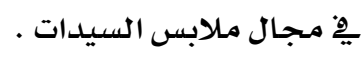

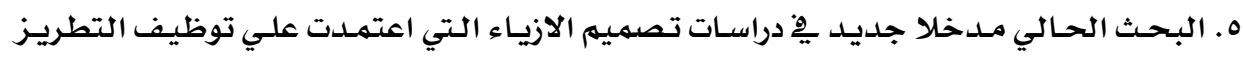

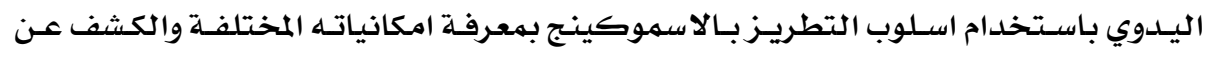

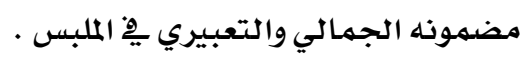

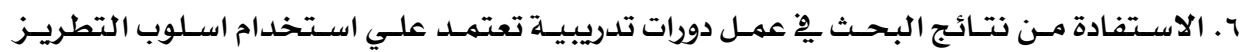

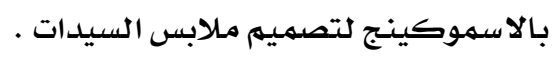

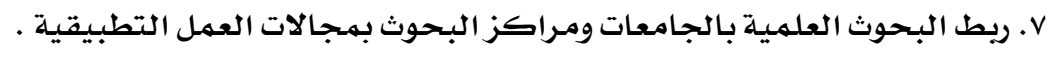

\section{همطاتمات البمث : • التصميي والتطريز:}

يعرف التطوير بأنه التحول من أشكال سـابقة إلى أشكال جديـدة وهو يشير إلى سلسلـة مـن

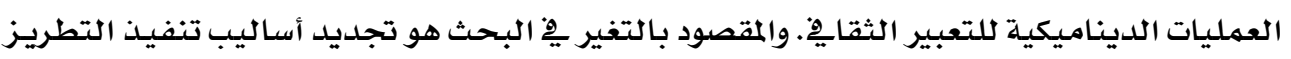


لملابس السيدات ـ أما التجديد فهو التطوير نحو ما هو أجود من سابقته أو وضع شي جديد يِّ مجـال

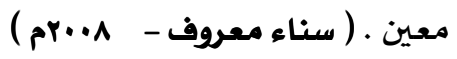

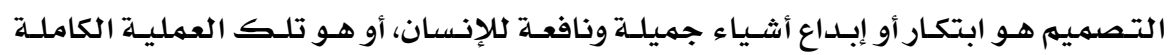

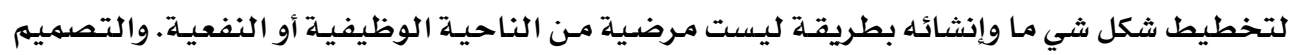

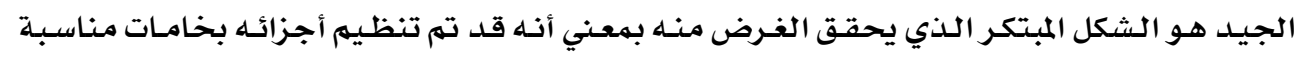

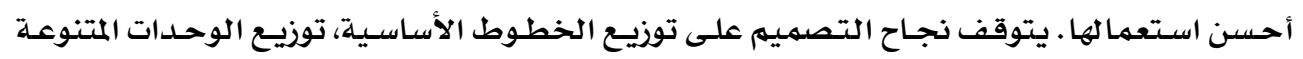

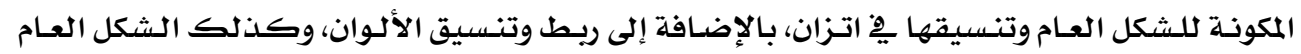

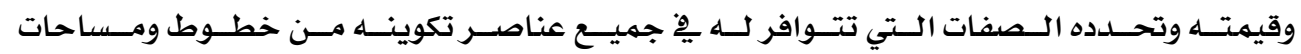

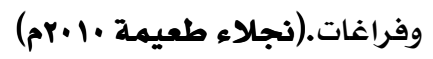

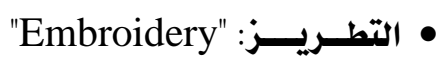

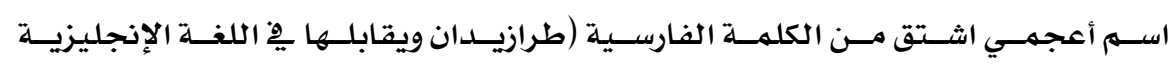

و وِّ اللغة الفرنسية Bmbroidery

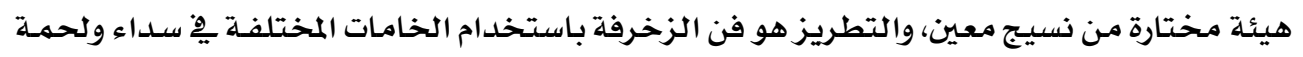

$$
\text { النسيج الذي يطرز عليه. }
$$

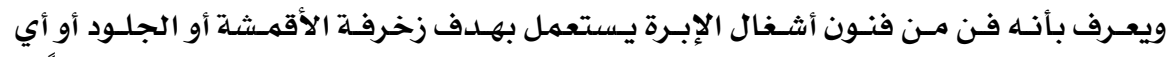

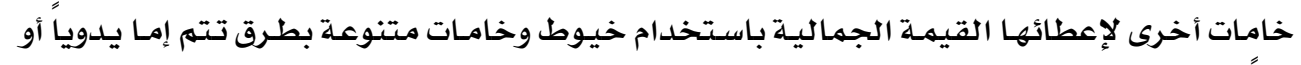

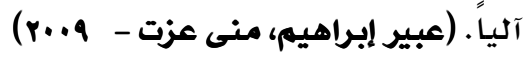

$$
\begin{aligned}
& \text { • }
\end{aligned}
$$

هو السمق ويقصد بـه اسلوب خـارجي فضفاض يرتدي لوقايسة الملابس مـن الاتساخ ويطرز

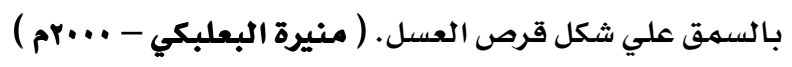

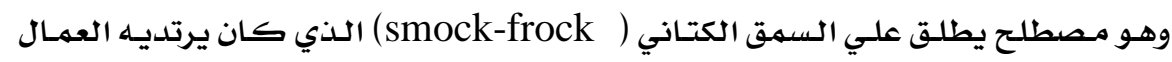

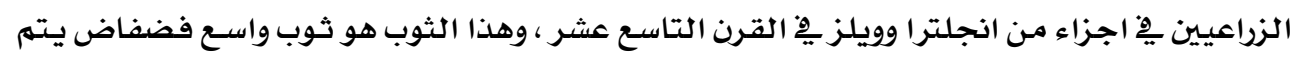

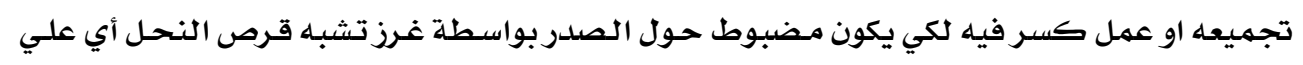

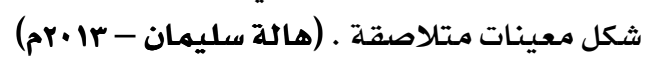

هدود البحث :

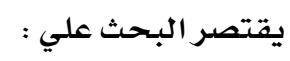

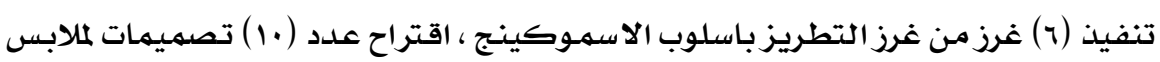

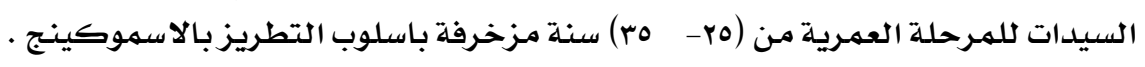




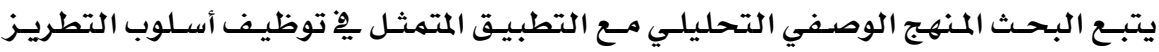

$$
\begin{aligned}
& \text { بالاسموكينج على مجموعه من ملابس السيدات . }
\end{aligned}
$$

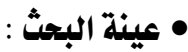

تكونت عينة البحث من (ع 1) مفردة موزعة على السادة المتخصصين يِّ مجال تصميه الازياء

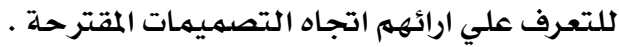

$$
\begin{aligned}
& \text { • أدوات البحث : }
\end{aligned}
$$

استمارة استبيان لقياس اراء المتخصصين تجاه التصميمات المقترحة ملحق رقم (1)

$$
\text { الإطار التطبيقي: }
$$

$$
\text { ويتتم ذلك من خلال الآتي: }
$$

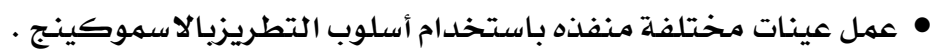

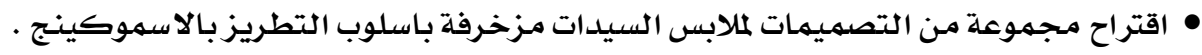

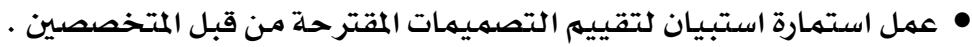

\section{الدراسة العمدلية:}

بغرض التحقق مـن فروض الدراسـة والمتمثلـلة ِِّ تسـاؤلات البحـث والوصـول إلى أهـدافها تم

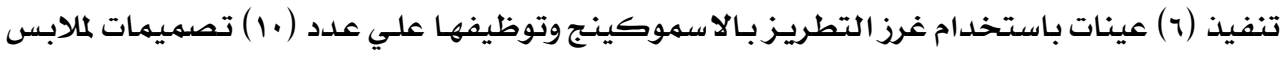

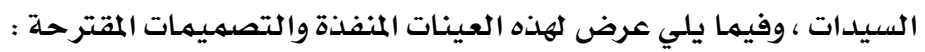

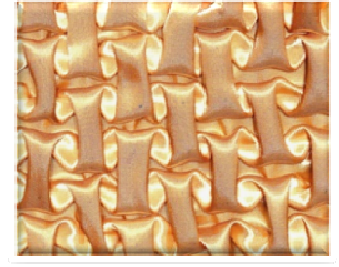

غرزة المستطيل

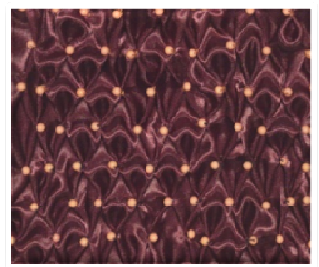

غرزة الزهرة الثنائية

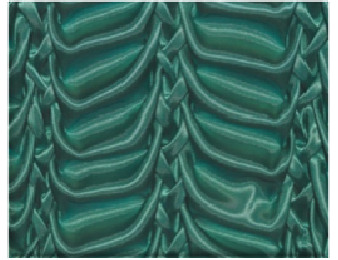

غرزة الضفيرة

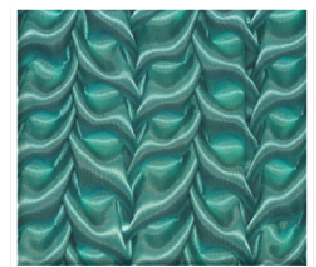

غرزة ورقة الشجر

الفرز المستخلمة :

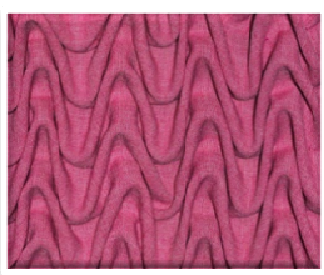

غرزة الموجة

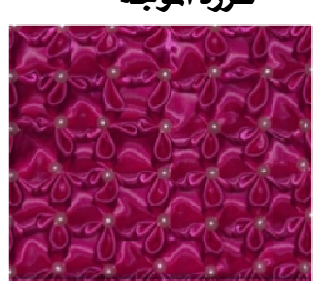

غرزة زهرة الياسمين الرياعية 
التصميسمات المقتزحة :

تصميم رقم (1)

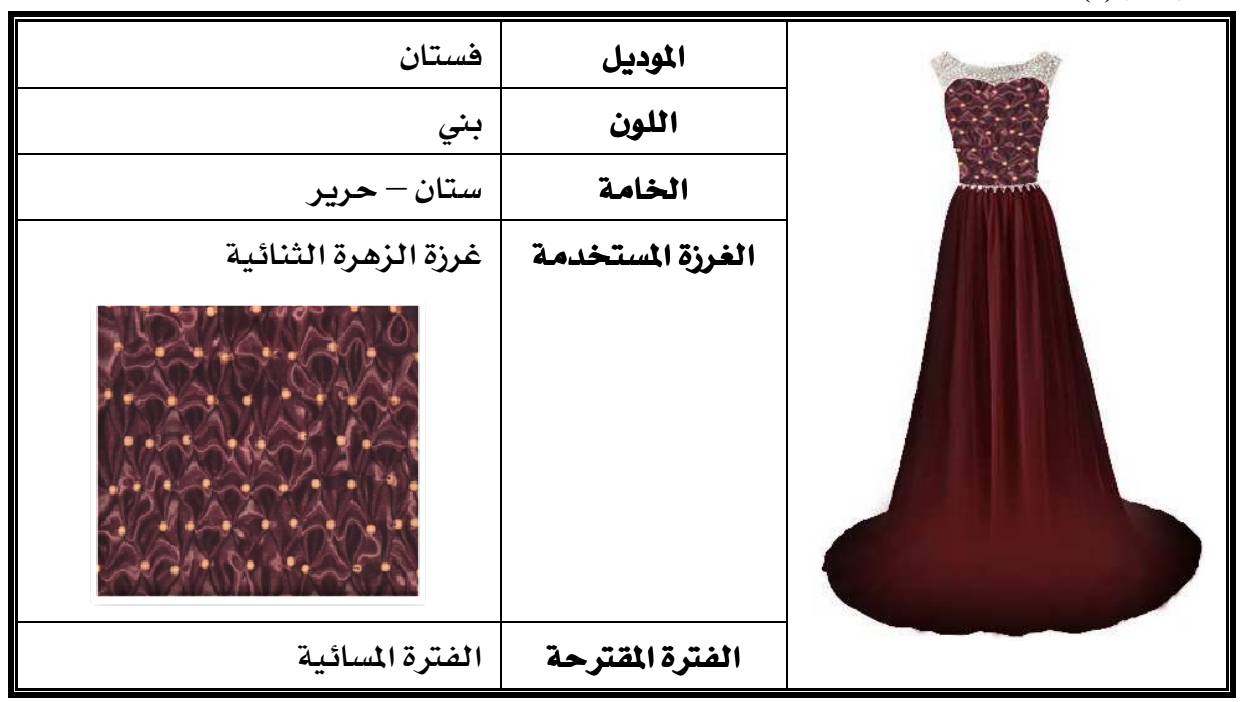

تصميم رقم (ن)

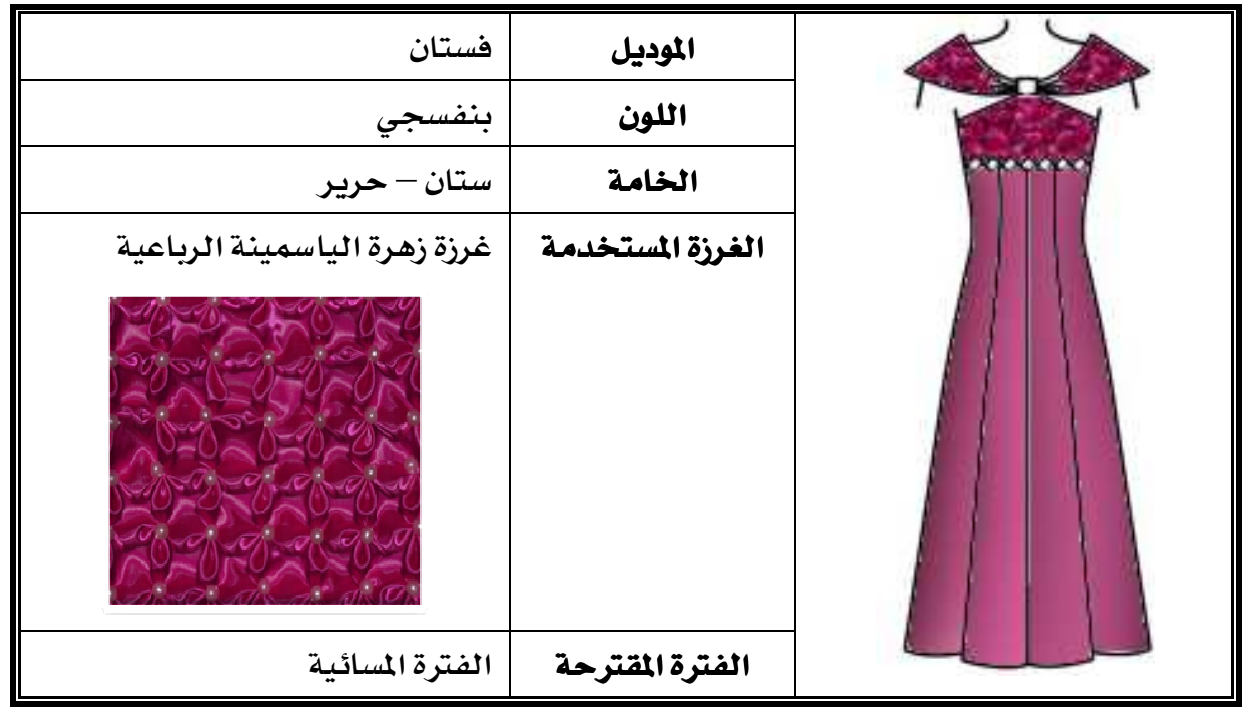


تصمييم رقم (广)

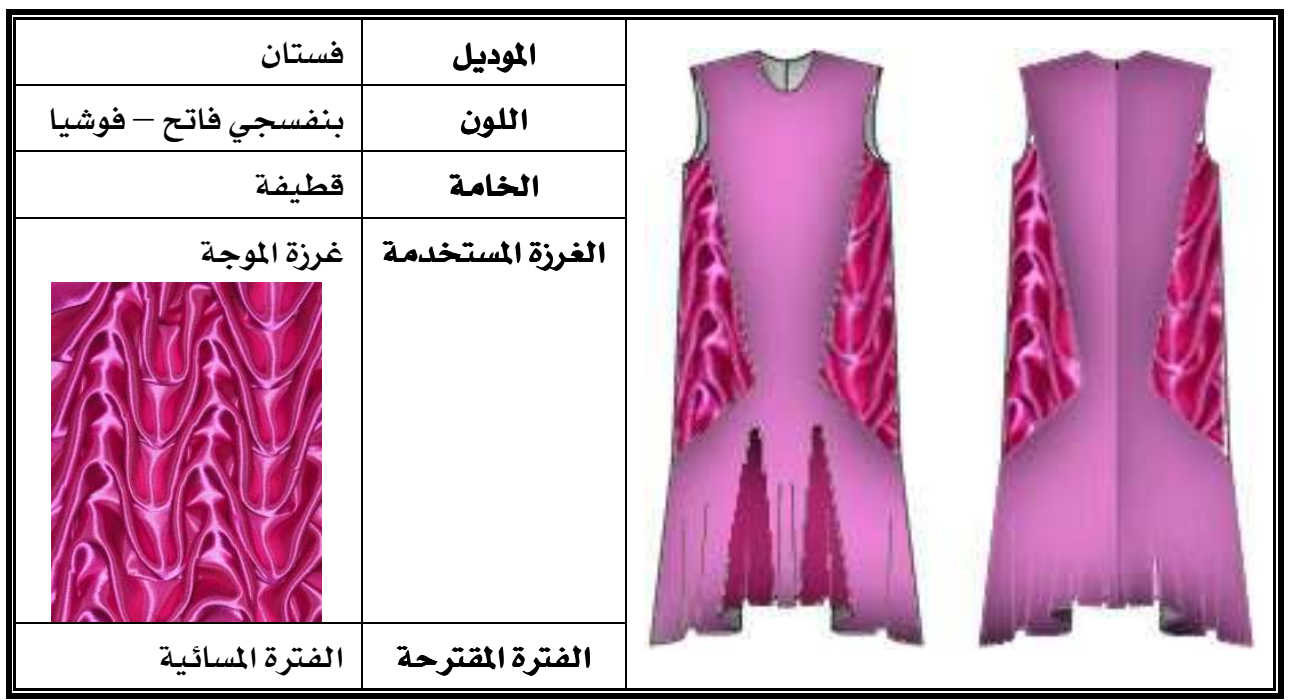

تصمييم رقم (₹)

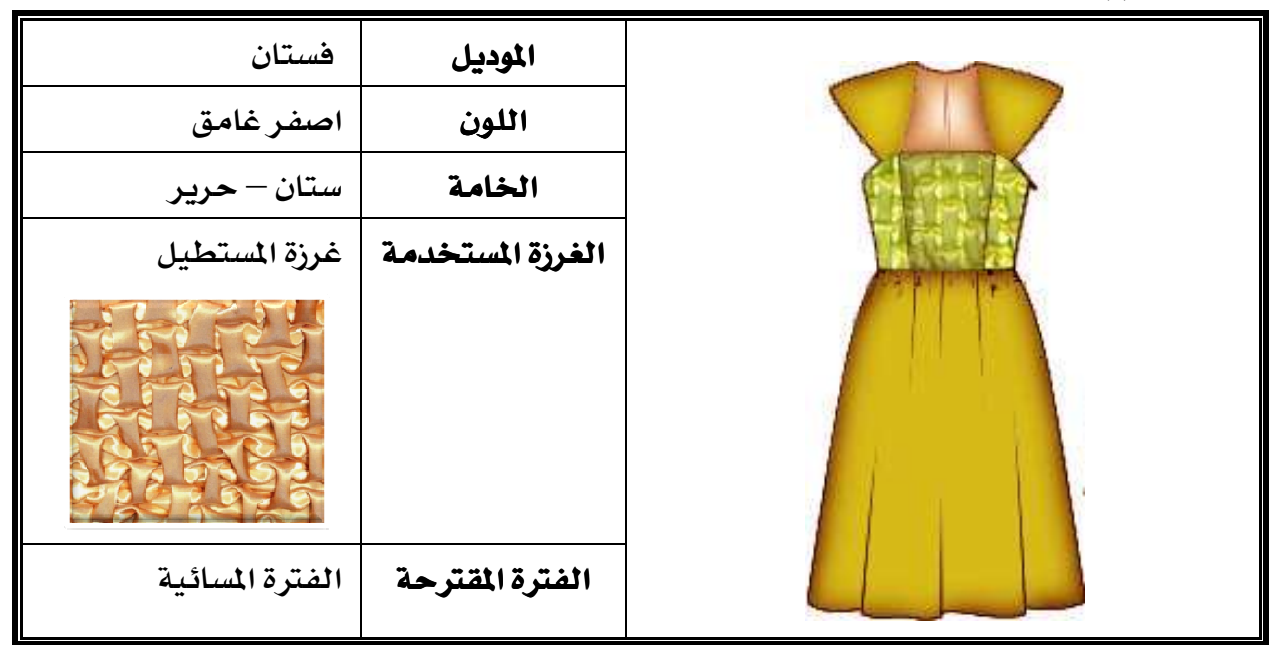



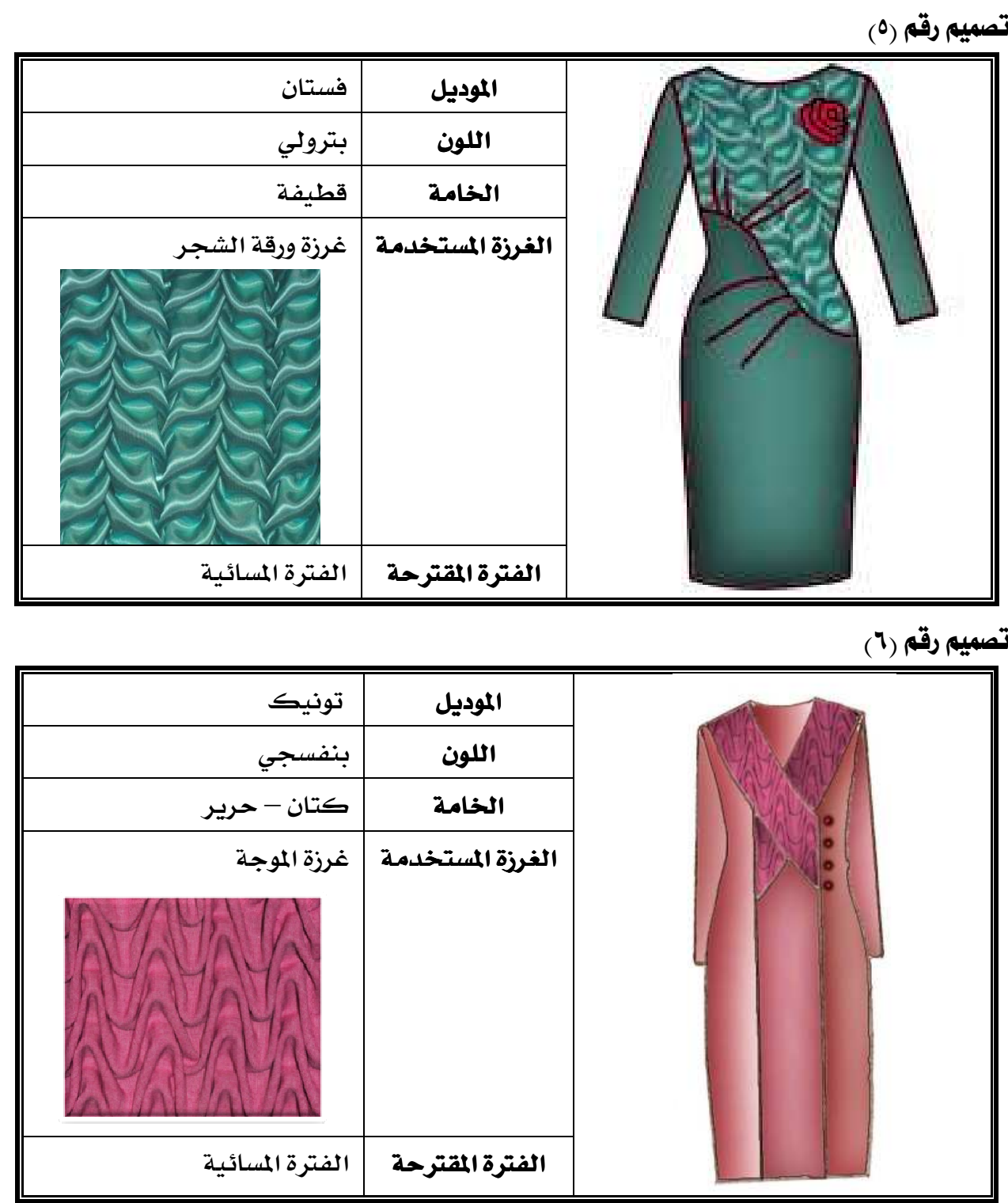


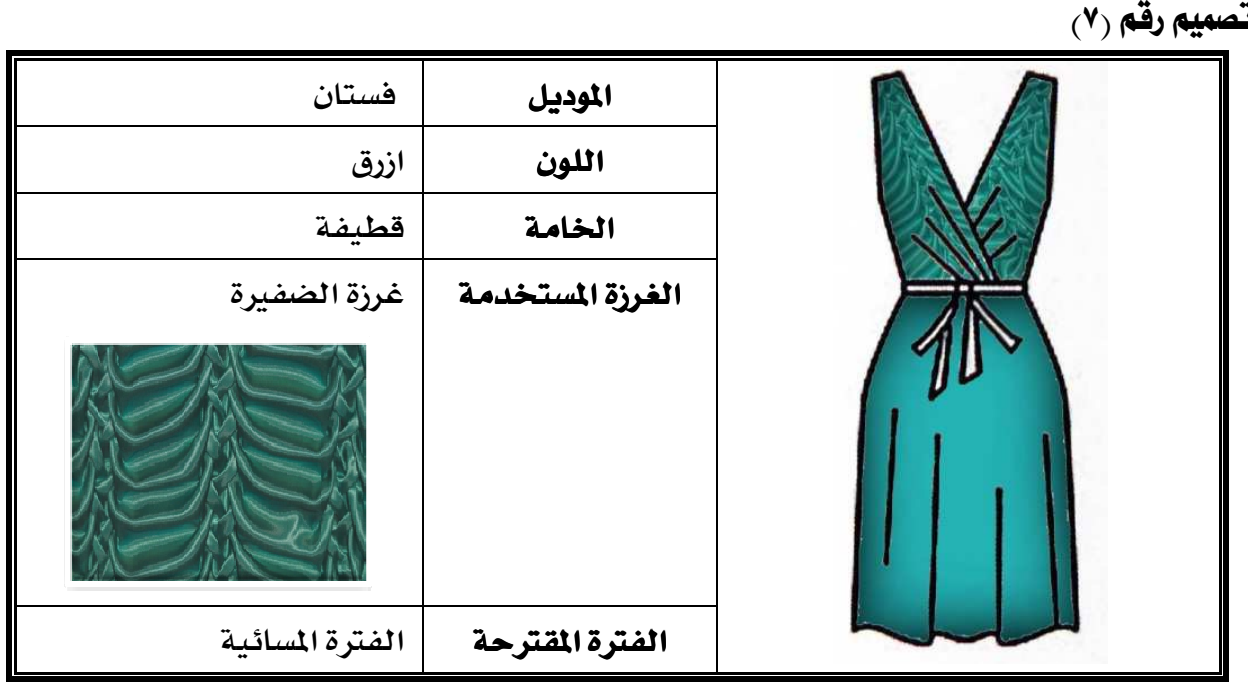

تصميي رقم (A)

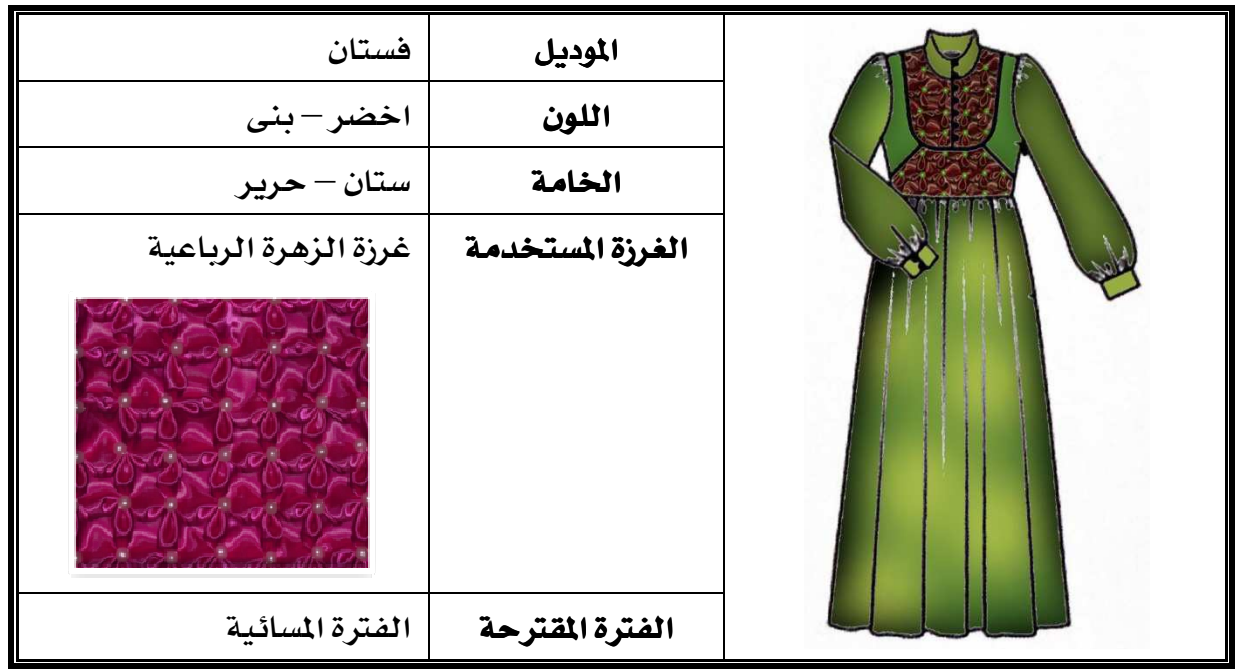




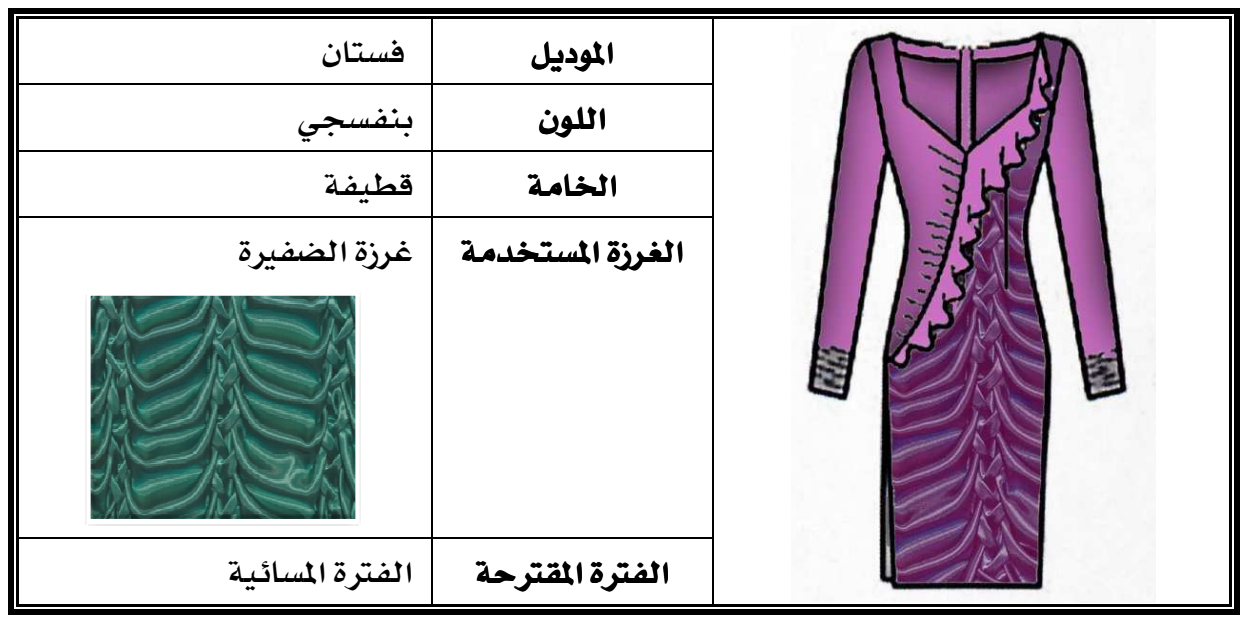
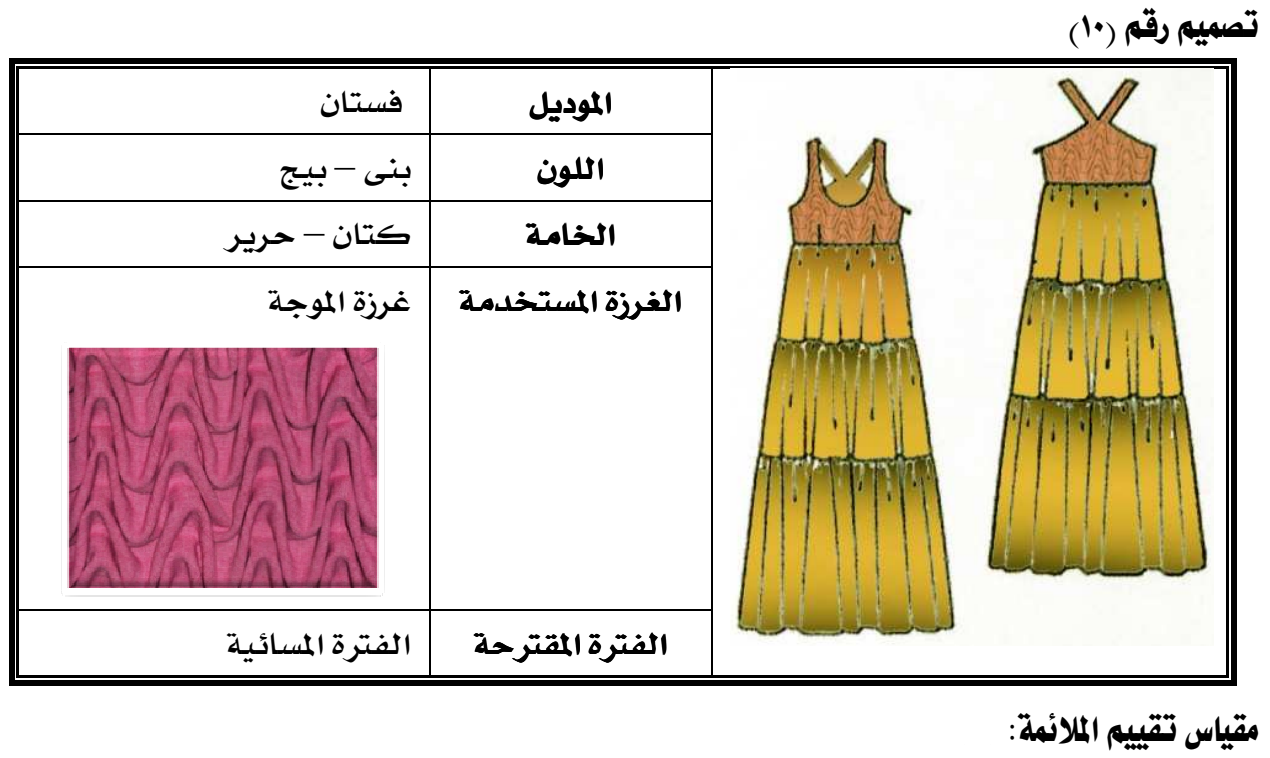

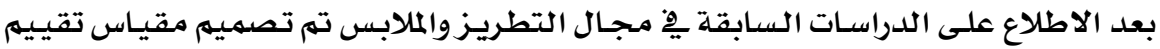

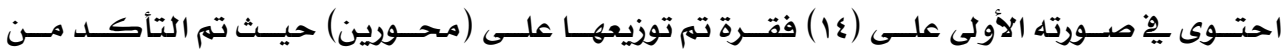
صدقه وثباته.

وصف استمارة الاستبيان:

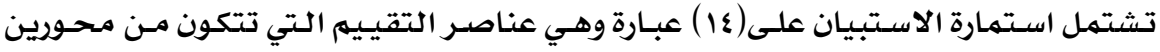

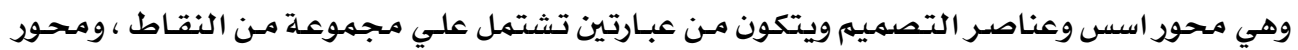




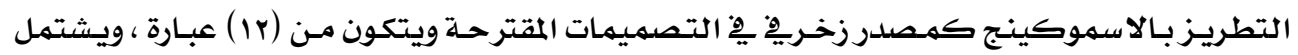

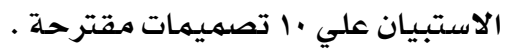

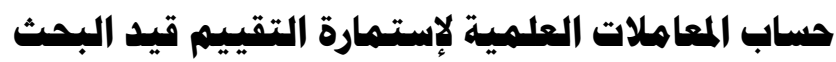
/ / حساب ثبات إستمارة التقيييم للتصميمات الخاصة بالبحث :

تم حساب ثبات إستمارة تقييم التصميمات الخاصة بالبحث بطريقتين مختلفتين هما :-

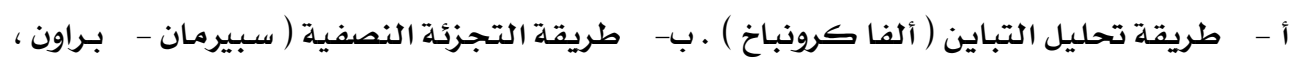

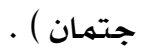

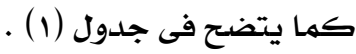

(1) (1) (1)

حساب معامل الثبات لاستمارة تقييم التصميمات الخاصة بالبحث بطريقتى (1)

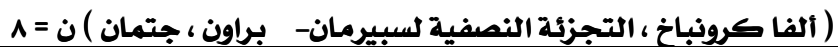

\begin{tabular}{|c|c|c|c|c|c|c|c|c|c|}
\hline \multicolumn{2}{|c|}{ التجزئة النصفية } & \multirow{2}{*}{ كرونباخ ألفا } & \multirow{2}{*}{ | العبارة | - } & \multirow{2}{*}{ المحور } & \multicolumn{2}{|c|}{ التجزئة النصفية } & \multirow{2}{*}{ ألفا كرونباخ } & \multirow{2}{*}{ العبارة } & \multirow{2}{*}{ المحور } \\
\hline جتمان & سبيرمان-براون & & & & جتمان & سبيرمان_براون & & & \\
\hline • • • & - 9 . & •, 9v7 & $r$ & \multirow{10}{*}{ كالأسموكينج } & , ,911 & •, वrA & •, 979 & 1 & \multirow{10}{*}{ أسس } \\
\hline •, ory & $\cdot, 919$ & $\cdot, q \vee v$ & $\varepsilon$ & & $\cdot, 9 \cdot 9$ & -, वr. & $\cdot, 978$ & r & \\
\hline$\cdot, 097$ & $\cdot, 991$ & $\cdot, 9 \vee 0$ & 0 & & •, वYร & •, वYE & •, arr & $r$ & \\
\hline$\cdot, 0 . \cdot$ & $\cdot, 7+1$ & $\cdot, 979$ & 7 & & •, var & $\cdot, 107$ & $\cdot, 970$ & $\varepsilon$ & \\
\hline$\cdot, 097$ & $\cdot, 991$ & •, qYo & $\checkmark$ & & •,970 & -,970 & $\cdot, 979$ & 0 & \\
\hline י י & •, 994 & -, 9Yo & $\wedge$ & & •, १६ז & $\cdot, 9 \leqslant V$ & •, qr. & 7 & \\
\hline$\cdot, 090$ & •, 998 & •, १Yo & 9 & & $\cdot, \wedge \wedge 9$ & •, Aar & $\cdot, 970$ & $\checkmark$ & \\
\hline$\cdot, 719$ & $\cdot, 99$. & •, qYo & 1. & & $\cdot, 9 \wedge \wedge$ & $\cdot, 919$ & $\cdot, 978$ & $\wedge$ & \\
\hline •, Trr & $\cdot, 99$. & $\cdot, 9 \vee 7$ & 11 & & $\cdot, 070$ & $\cdot, 99 \mathrm{~V}$ & $\cdot, 9 \vee 7$ & 1 & \\
\hline$\cdot, 9 \Lambda$. & $\cdot, 971$ & •, १ห५ & ir & & $\cdot, 090$ & -, १9४ & •, qYo & $r$ & \\
\hline
\end{tabular}

* قيمة ألفا كرونباخ الجدولية = qVq, .

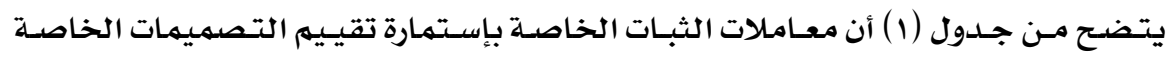

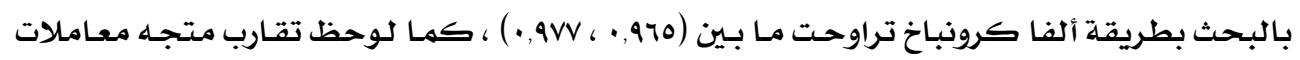

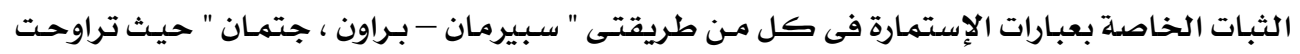

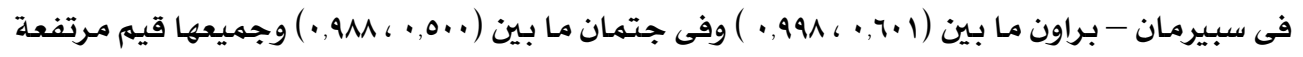

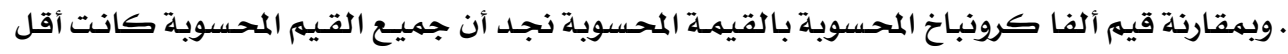

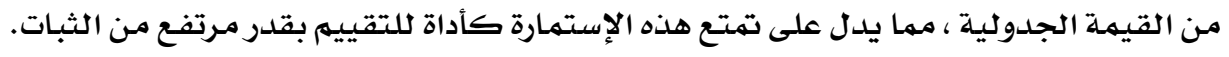


r/ حساب صلدق إستمارة تقييي التصميمات الخاصة بالبحث ( الإتساق الداخلى ) :

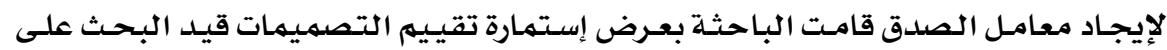

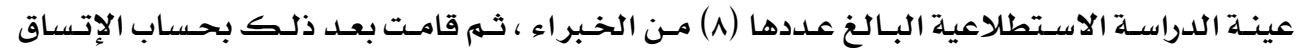

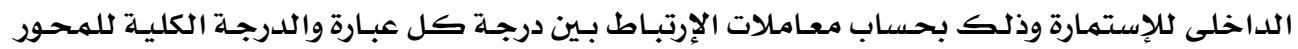

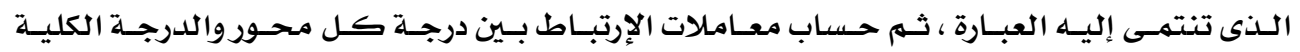

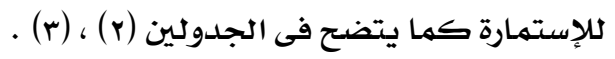

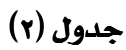

معامل الإرتباط بين درجة كل عبارة والدرجة الكلية للمحور الذى تنتمى إليه

\begin{tabular}{|c|c|c|c|c|c|}
\hline معامل الإرتباط & رقم العبارة & المحور & معامل الإرتباط & رقم العبارة & المحور \\
\hline$* *, 971$ & $r$ & \multirow{10}{*}{ كمصلار زخرفى التطرينج } & $* *_{\bullet}, 901$ & 1 & \multirow{10}{*}{ التصميم وعناصر } \\
\hline$* *$, १४१ & $\xi$ & & $* *_{,}, 90 \varepsilon$ & $r$ & \\
\hline$* *, 997$ & 0 & & 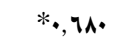 & $r$ & \\
\hline$*_{., 701}$ & 7 & & $* *_{,}$, qr $r$ & $\varepsilon$ & \\
\hline$* *_{\bullet, 997}$ & $\checkmark$ & & $* *_{\text {, , q }}$ & 0 & \\
\hline$* *, 9 \wedge 0$ & $\wedge$ & & $* *_{\text {, }, \text { grr }}$ & 7 & \\
\hline 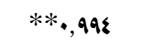 & 9 & & $* *, 9 \wedge 7$ & $\checkmark$ & \\
\hline$*_{*}^{*}, 9 \Lambda$. & 1. & & $* *$, , $90 \mathrm{~V}$ & $\Lambda$ & \\
\hline$* *, 911$ & 11 & & $* *, 990$ & 1 & \\
\hline$* *, 971$ & ir & & $* *, 99 \xi$ & $r$ & \\
\hline
\end{tabular}

* دال عند مستوى معنوية ( ه., • ) )

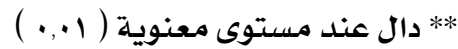

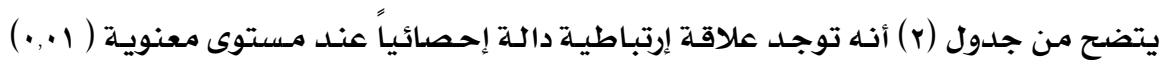

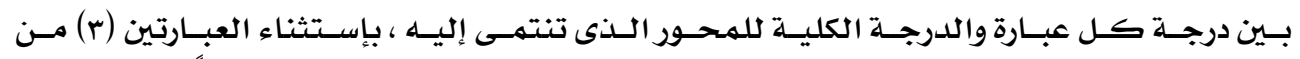

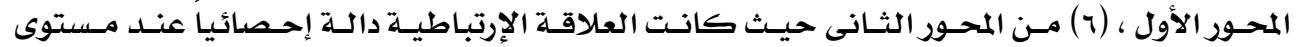
معنويـة (0., •).

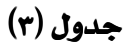

معامل الارتباط بن درجة كل محوروالدرجة الكلية لاستمارة تقييم التصميمات الخاصة بالبحث ( الاتساق الداخلي )

\begin{tabular}{|c|c|c|}
\hline معامل الإرتباط & محورى استمارة تقيييم التصميمات & $\therefore$ \\
\hline$* *, 910$ & أسس وعناصر التصميي & 1 \\
\hline **, q94 & التطريز بالإسموكينج كمصدر زخرفى & $r$ \\
\hline
\end{tabular}

(** دال عند مستوى معنوية ( +. (• ) ) 


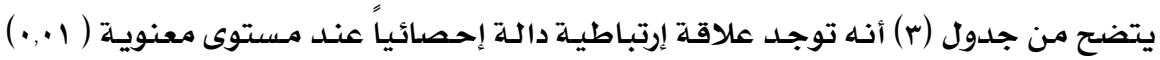

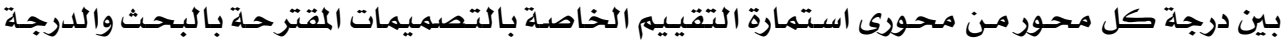

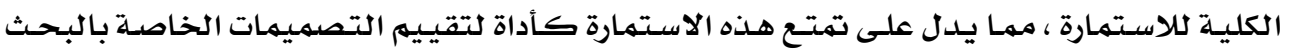

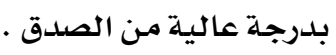

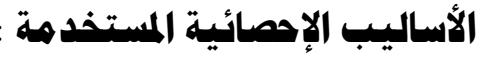

• تحليل التباين ( ألفا كرونباخ ) .

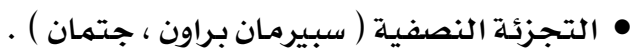

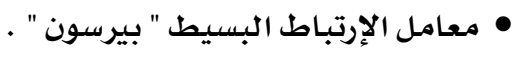

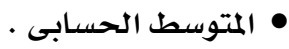

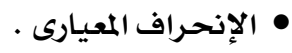

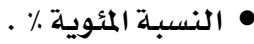

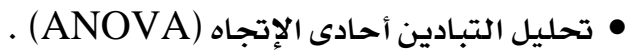

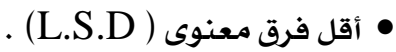

النتائج وهناقشاتها

وفيمـا يلـي عرض للنتـائج المتعلقـة بالتصميمات المنفـذة حيـث تم تنفيـذ ( ) عينـات مطـرزه

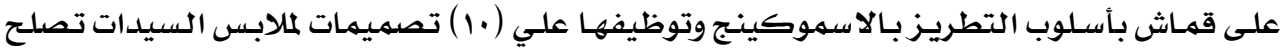

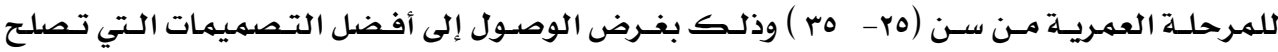

لتلك المرحلة.

جدول (ع) جدول التصميمات لكل محور من المحاور المقترحة حسب معامل الاتفاق لأراء المحكمين

\begin{tabular}{|c|c|c|}
\hline تقيييم المحور الثانى & تقيييم المحور الأول & رقم التصميم \\
\hline 0.8 & rrq & التصميم رقم (ا) \\
\hline « & ral & التصميه رقم (r) \\
\hline rrM & TYS & التصميم رقم (") \\
\hline ६१. & $r$ r. & التصميم رقم (\&) \\
\hline \&rr & $\mathrm{rMA}$ & التصميم رقم (0) \\
\hline \&rr & YAA & التصميه رقم (1) \\
\hline 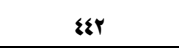 & ral & التصميم رقم (v) \\
\hline 807 & r.\& & التصميم رقم (A) \\
\hline$\$ 70$ & rII & التصميم رقم (9) \\
\hline \$0. & r.\& & التصميم رقم (•) \\
\hline
\end{tabular}


جدول (0)

تقييم التصميمات المقترحة للمنتجات حسب معاملات الاتفاق

\begin{tabular}{|c|c|}
\hline النسبة|المئوية & التقدير \\
\hline من •.1\% إلى •9.\% & متاز \\
\hline 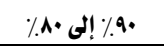 & جيدجداً \\
\hline 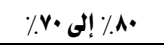 & جيد \\
\hline 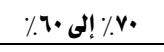 & متوسط \\
\hline أقل من • ٪\% & ضميف \\
\hline
\end{tabular}

يتضح من جدول (0) ما يلى :-

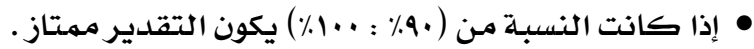

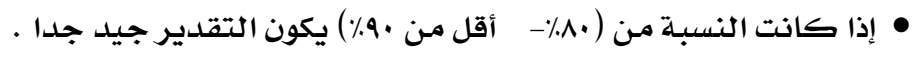

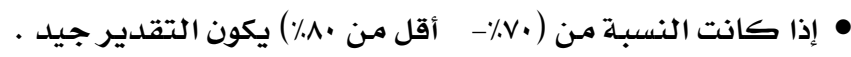

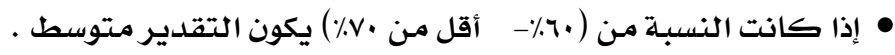

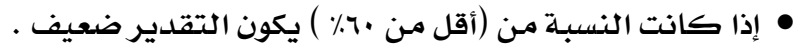

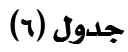

التقديرات الكلية للتصميمات

\begin{tabular}{|c|c|c|c|c|}
\hline الترتيب & التقدير & النسبة \% & الدرجة الكلية للتقييي & رقم التصميم \\
\hline الأول & متثاز & $\%$ & $\wedge \varepsilon \cdot$ & التصميم رقم (1) \\
\hline السادس & جيد جلداً & $\%$ AY, Y Y & vrr & التصميم رقه (r) \\
\hline العاشر & متوسط & $\% 77,7 \vee$ & 07. & التصميم رقم (r) \\
\hline الثانى & متتاز & $\% 97,8 \%$ & Al. & التصميم رقم (₹) \\
\hline الثامن & جيد جلداً & $\% \wedge \Delta, \vee n$ & vr. & التصميم رقه (0) \\
\hline الثامن مكرر & جيد جداً & $\% \wedge \Delta, \mathrm{n})$ & rre & التصميم رقم (1) \\
\hline السادس مكرر & جيد جداً & $\%$ \%V, Yq & VHT & التصميم رقم(v) \\
\hline الرابع & مثتاز & $\% q \cdot, \sum \wedge$ & vi. & التصميم رقم (^) \\
\hline الثاث & مثتاز & $\% 9 r, r \Lambda$ & rvy & التصميم رقه (9) \\
\hline الخامس & جيد جداً & $\% \wedge 9, \vee 9$ & vos & التصمييم رقم (*) \\
\hline
\end{tabular}




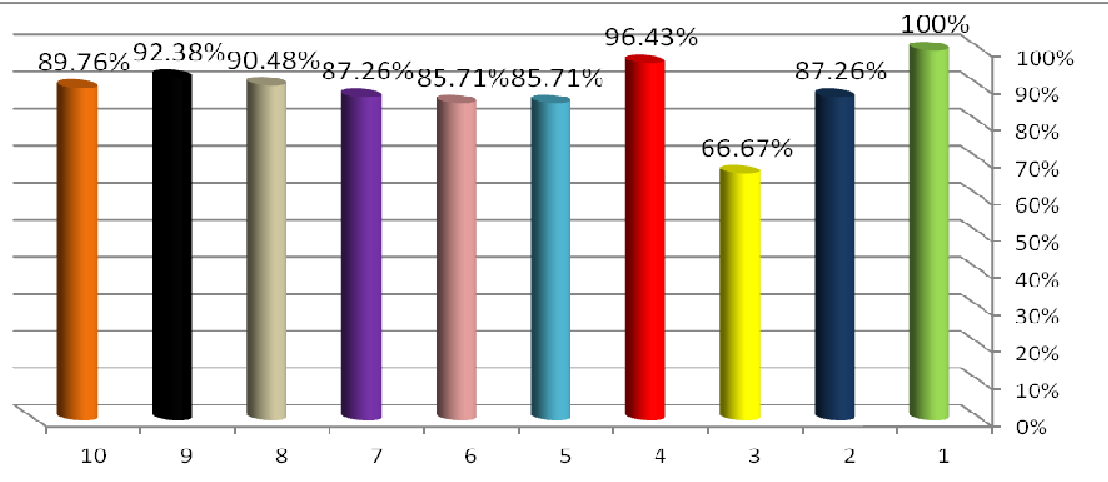

\section{شكل (1)}

التقديرات الكلية للتصميمات

$$
\begin{aligned}
& \text { يتضح من جدول (7) وشكل (1 ) ما يلى : } \\
& \text { • حصلت التصميمات ( } 1 \text { ، ع ، ^ ، 9 ) على تقدير " مهتاز " . }
\end{aligned}
$$

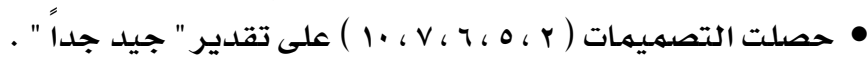

$$
\begin{aligned}
& \text { • حصل التصميم (r ) على تقدير " متوسط " . } \\
& \text { • لم تحصل أى من التصميمات على تقدير " جيد " . } \\
& \text { • لم تحصل أى من التصميمـات على تقدير " مقبول " . } \\
& \text { • لم تحصل أى من التصسميمات على تقدير " ضعيف " . } \\
& \text { وكما يتضح فى جدول آل من التمهيهات }
\end{aligned}
$$

\begin{tabular}{|c|c|c|}
\hline العدد & التصميمات & التقديرات \\
\hline$\varepsilon$ & $9 / \wedge / \xi / 1$ & مقتاز \\
\hline 0 & $1 . / r / 7 / 0 / r$ & جيد جداً \\
\hline - & - & جيد \\
\hline 1 & $r$ & متوسط \\
\hline- & - & مقبول \\
\hline - & - & ضعيف \\
\hline 10 & \multicolumn{2}{|c|}{ الإجماثى } \\
\hline
\end{tabular}

جدول 


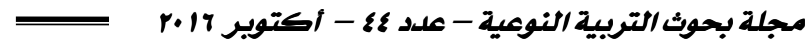

جدول (^) المتوسط الحسابي والانحراف المعياري والدرجة الكلية وترتيب التصميمات وتقديرها طبقا لاستحابات السادة المحكهـين

\begin{tabular}{|c|c|c|c|c|c|c|}
\hline الترتيب & التقدير & النسبة المئوية & الإنحراف الماعيارى & المتوسط الحسابى & الدرجة الكلية & رقم التصميي \\
\hline الأول & مثتاز & $\% 1$. & $\bullet, \cdots$ & $\xi Y, \cdots$ & $\wedge \varepsilon$. & التصميه رقه (1) \\
\hline السادس & جيد جداً & $\%$ \% Y, YY & •, $7 r 1$ & $\mathrm{rq}, 70$. & Vrr & التصميه رقم (r) \\
\hline العاشر & متوسط & $\% 77,7 v$ & $\bullet, \bullet \bullet$ & $r \wedge, \cdots$ & 07. & التصمييم رقم (r) \\
\hline الثانى & 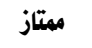 & $\% 97,8 r$ & $\cdot, 7 \cdot v$ & $\varepsilon \cdot 0+\cdots$ & Al. & التصميه رقم (₹) \\
\hline الثامز & جيد جداً & $\% \wedge 0, \vee 1$ & $\bullet, \cdots$ & rq, $\cdots$ & VY. & التصميه رقه (0) \\
\hline الثامن مكرر & جيد جداً & $\% \wedge 0, \vee 1$ & $\bullet, \bullet \bullet$ & rq,,$\cdots$ & Vr. & التصميه رقه (1) \\
\hline السادس مكرر & جيد جلاً & $\%$ \% Y, YY & $\cdot, 7 \times 1$ & rq, 70. & VHr & التصميي رقم(v) \\
\hline الرابع & 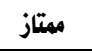 & $\% q \cdot, 2 \Lambda$ & $\bullet, \bullet \bullet$ & rA, $\cdots$ & VY. & التصميم رقم (^) \\
\hline الثالث & معتاز & $\%$ qr, rA & $\bullet, \$ 1$ & rA,,$\cdots$ & VVY & التصمييم رقم (9) \\
\hline الخامس & جيد جداً & $\% \wedge 9, \vee 7$ & $\cdot, 0 \mathrm{VI}$ & $r v, v \cdots$ & Yos & التصميه رقم (•) \\
\hline
\end{tabular}

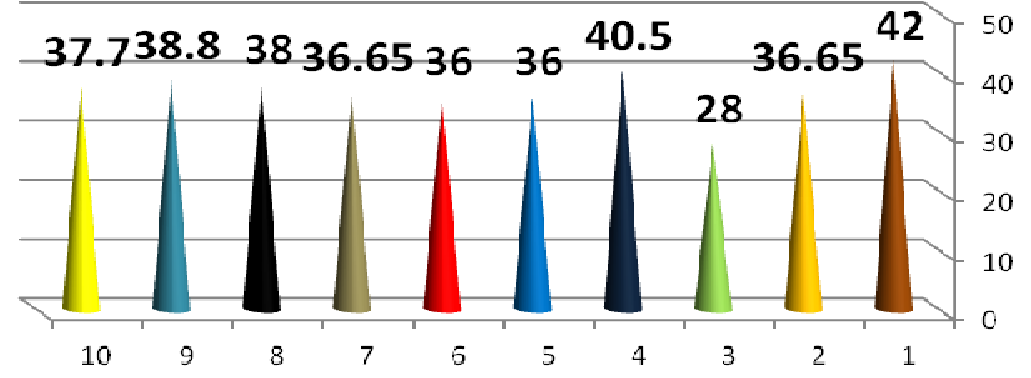

شكل (r) المتوسط الحسابى للتقديرات الكلية للتصميمات قيد البحث

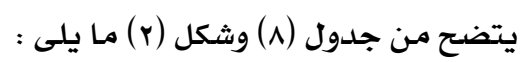

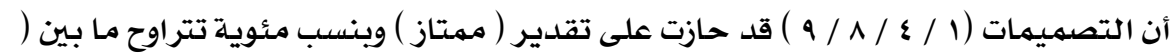

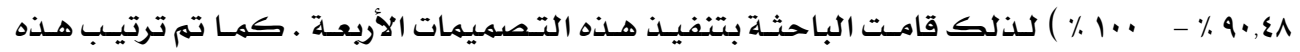

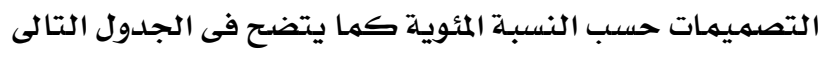


جدول (9) ترتيب التصميمات المنفذة قيد البحث وفقاً للنسبة المئوية

\begin{tabular}{|c|c|c|c|}
\hline الترتيب & النسبة المئوية & التصمييم & ค \\
\hline الأول & $\% 1 .$. & الأول & 1 \\
\hline الثانى & $\%$ \% , हा & الرابع & $r$ \\
\hline الثالث & $\%$ ar, rA & التاسع & $r$ \\
\hline الرابع & $\% q \cdot,\{\wedge$ & الثامن & $\xi$ \\
\hline
\end{tabular}

جدول ( • 1 ) التقييم الكلى للمحور الأول ( أسس وعناصر التصميم ) للتصميمات المنفذه تحت الدراسة

\begin{tabular}{|c|c|c|c|c|c|}
\hline التصمييم رقم (^) & |التصميم رقم (9) & |التصميه رقم (₹) & التصميم رقم (1) & \multicolumn{2}{|c|}{ أسس وعناصر التصميي } \\
\hline ra & rq & ६. & $\varepsilon r$ & الوحلدة & \multirow{4}{*}{ العلمية للتصميي } \\
\hline ra & rA & $\$ 1$ & $\varepsilon r$ & النسبة والتناسب & \\
\hline ra & ra & ra & $\varepsilon r$ & الاتزان & \\
\hline ra & ra & $\varepsilon \cdot$ & $\xi r$ & الإيقاع & \\
\hline ra & rq & $\varepsilon$ & $\xi r$ & الخط & \multirow{4}{*}{ العناصر } \\
\hline ra & rq & ६. & $\varepsilon r$ & الشكل & \\
\hline$r \Lambda$ & rq & ६. & $\{r$ & الحجم الجم & \\
\hline ra & rq & ६. & $\{r$ & اللوز & \\
\hline
\end{tabular}

$$
\begin{aligned}
& \text { يتضح من جدول (· م) ما يلى : } \\
& \text { 1- حاز التصميم رقم (1) على المركز الأول : }
\end{aligned}
$$

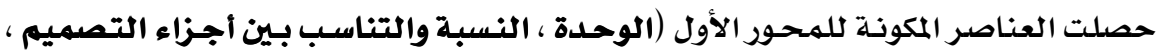

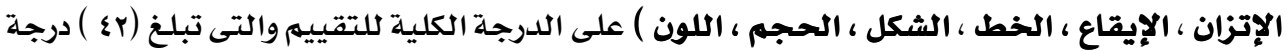

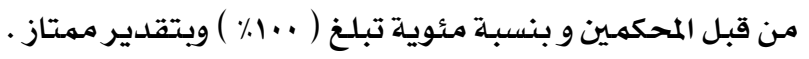

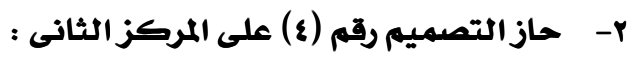

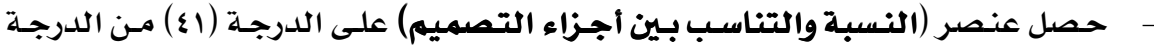

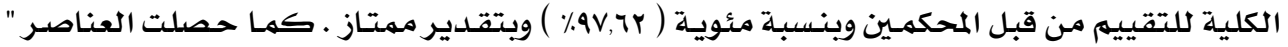

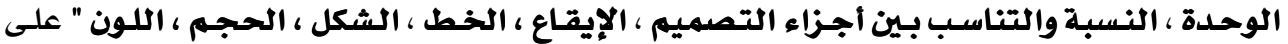

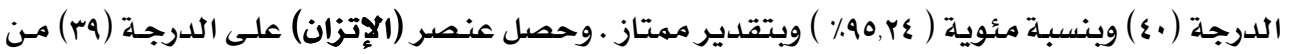

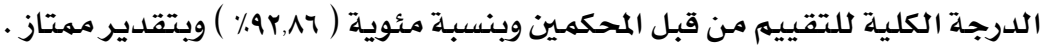
r- حاز التصميم رقم (9) على المركز الثالث :

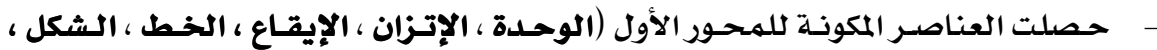

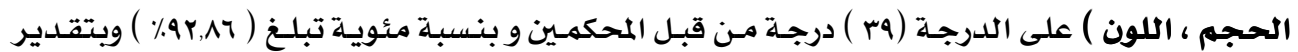




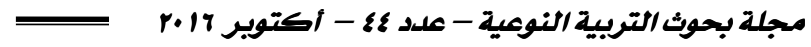

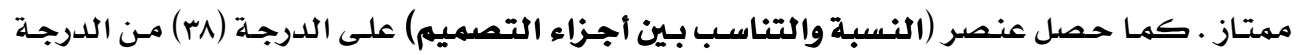

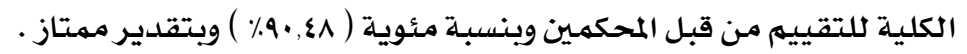

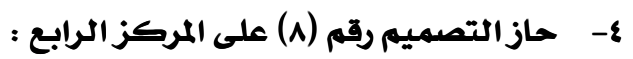

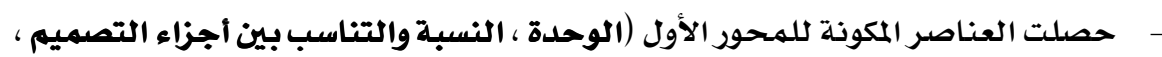

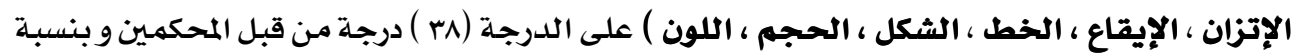

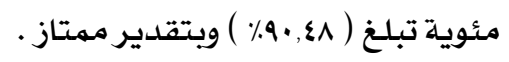

جدول ( 11 ) التقييم الكلى للمحور الثانى ( التطريز بالأسموكينج كمصدر زخرفى )

\begin{tabular}{|c|c|c|c|c|c|}
\hline \multicolumn{6}{|c|}{ للتصميمات المنفذه تحت الدراسة } \\
\hline التصميم (A) & التصميم (9) & رقم (ع) & رقمم (التصيم) & التطريز بالأسموكينج كمصدر زخرفى & \\
\hline ra & rq & $\S$ & $\varepsilon r$ & يحقق اسلوب التطريز المستخدم دور اساسي في بناء التصميه. & \multirow{12}{*}{ بالأسموكينج } \\
\hline ra & ra & § & $\varepsilon r$ & يتحقق في التصميم توظيف جيد لاسلوب التطريز المستخدم . & \\
\hline ra & ra & $\xi$ & \&r & يعطي اسلوب التطريز المستخدم تتيزا للتصييم المقتزح. & \\
\hline ra & rq & $\$$ & $\varepsilon r$ & توافق الفرز المستخدمة مع التصميم . & \\
\hline ra & ra & \$1 & sr & ل دقة تنفيذ الفرزة المستخدمة . & \\
\hline ra & ra & $\xi$ & \&r & يتناسب توزيع الفرزة مع التصميه المقترح. & \\
\hline ra & ra & \$1 & $\xi r$ & يتوافق اسلوب التطريز المستخدم مع الالوان المختارة للتصييم. & \\
\hline ra & ra & $\S$ & st & يتوافق اسلوب التطريز المستخدم مع المظهر السطحي للخامة. & \\
\hline ra & ra & $\$$ & st & يحقق التصميم المقترح الناحية الجمالية والفنية . & \\
\hline rA & ra & $\S$ & $\varepsilon r$ & يعقق التصميم المقترح الناحية الوظيفية . & \\
\hline ra & ra & $\S$ & sr & يحقق التصميه المقترح نوعا من الفردية والتميز لمرتديه . & \\
\hline ra & rq & $\S$ & st & يتناسب التصميه المقترح مع المرحلة العمرية المقترحة (من ro_ror سنة ) & \\
\hline
\end{tabular}

$$
\begin{aligned}
& \text { يتضح من جدول (11) مـا يلى : } \\
& \text { 1- حاز التصميم رقم (1) على المركز الأول : }
\end{aligned}
$$

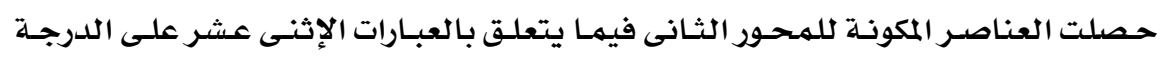

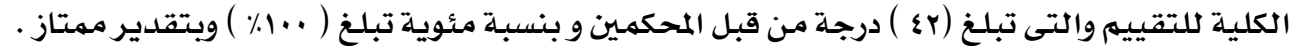

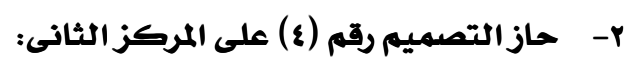

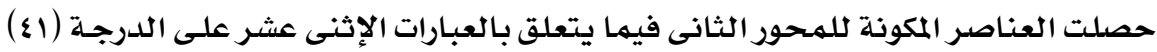

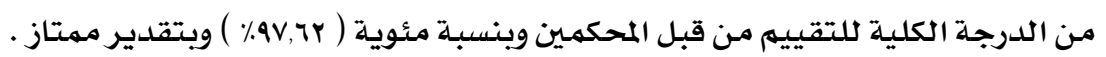

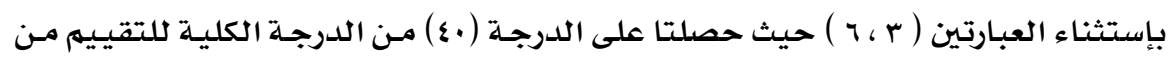

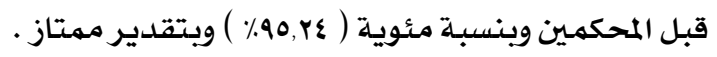




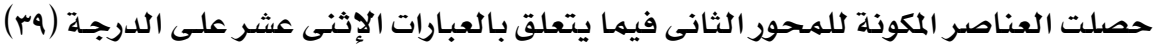

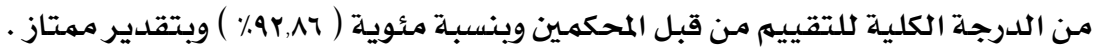

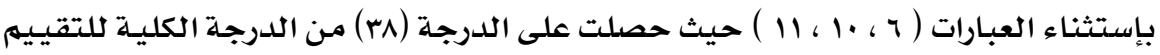

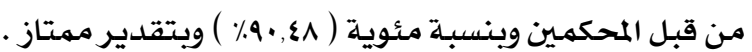

$$
\begin{aligned}
& \text { ع- حاز التصميم رقم (^) على المركز الرابع : }
\end{aligned}
$$

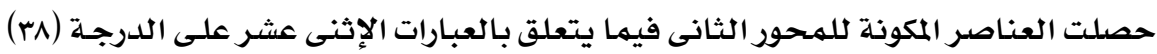

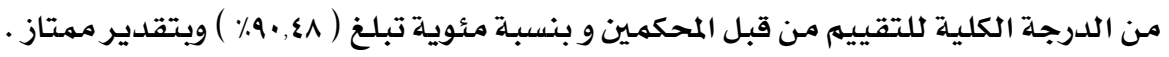

جدول (r) التقييم الكلى للمحورين الأول والثانى والدرجة الكلية للتصميمات المنفذة تحت الدراسة

\begin{tabular}{|c|c|c|c|c|c|}
\hline \multirow{2}{*}{ الترتيب } & \multirow{2}{*}{ الكلية } & \multirow{2}{*}{ التطريز بالأسموكينج كمصدر زخرفى المحور الثانى } & \multicolumn{2}{|c|}{ المحور الأول } & \multirow{2}{*}{ رقم التصميم } \\
\hline & & & العناصر الأساسية للتصميم & الأسس العلمية للتصميم & \\
\hline الأول & 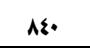 & 0.8 & 171 & 171 & (1) \\
\hline الثانى & Al. & \$q. & 17. & 17. & $(\boldsymbol{\xi})$ \\
\hline الثالث & rvY & $\$ 70$ & 107 & 100 & (9) \\
\hline 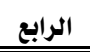 & vi. & \$07 & lor & 10r & $(\wedge)$ \\
\hline
\end{tabular}
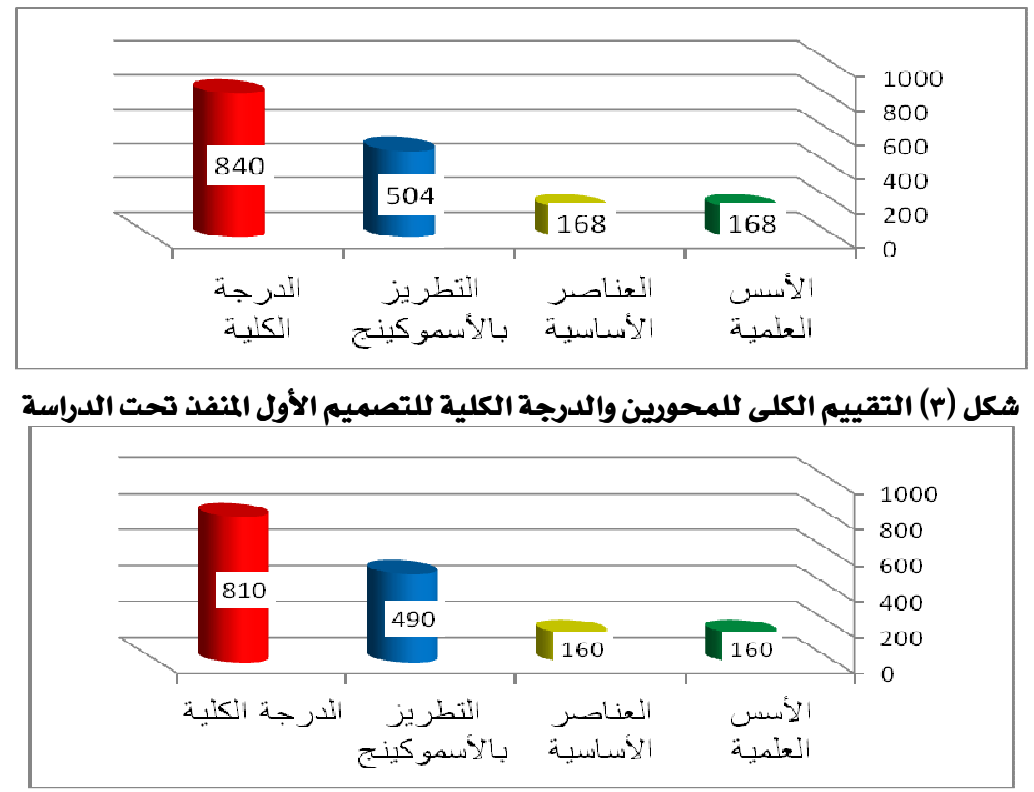

شكل (ع) التقييم الكلى للمحورين والدرجة الكلية للتصميم الثانى المنفذ تحت الدراسة 

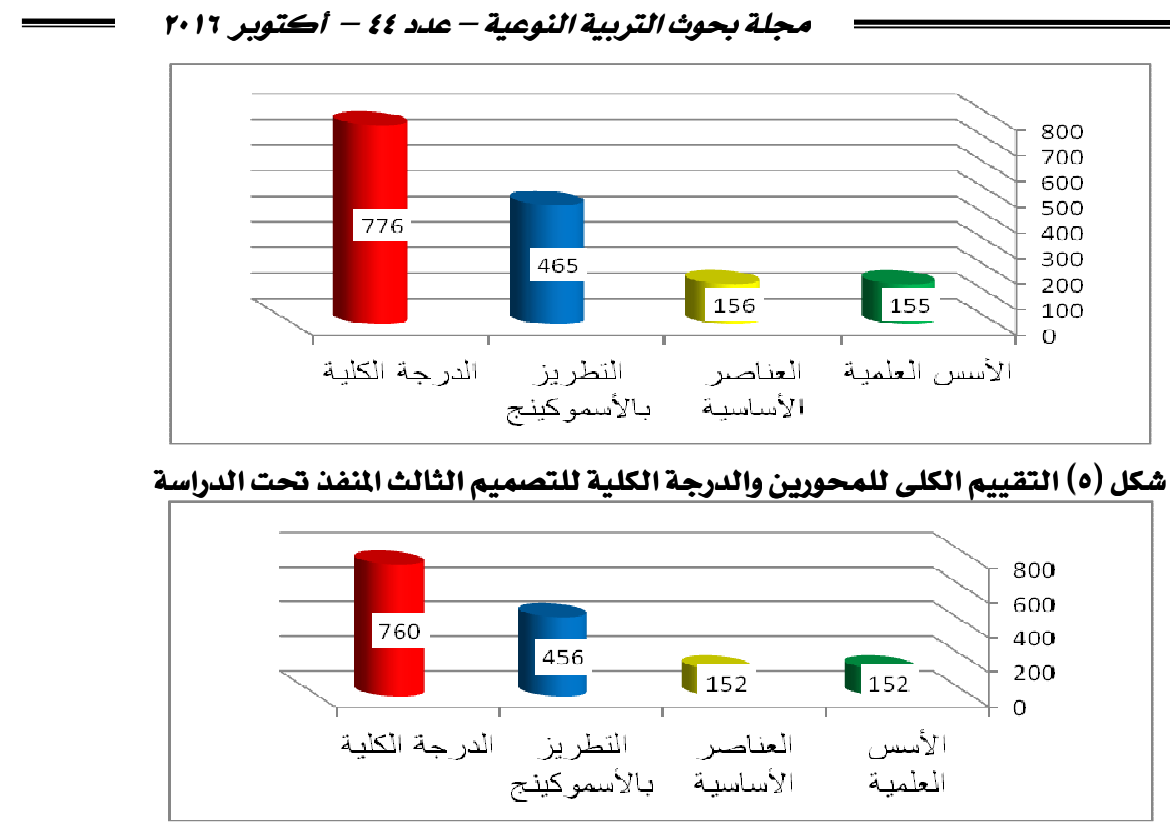

ثكل (ج) التقييم الكلى للمحورين والدرجة الكلية للتصميم الرابع المنفذ تحت الدراسة

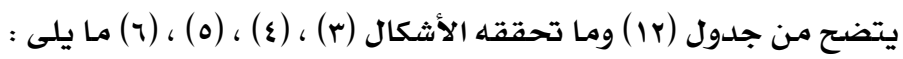
• أن التقديرات الكلية بالنسبة للتصميم الحائز على المركز الأول (1) :

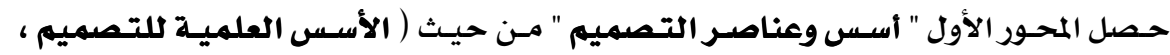

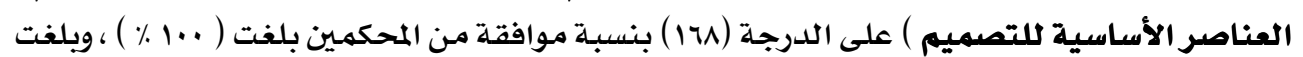

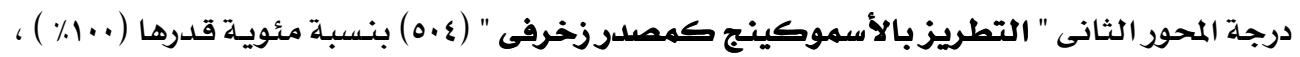

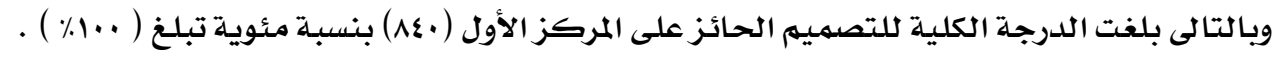
• أن التقديرات الكلية بالنسبة للتصميم الحائز على المركز الثانى (ع) :

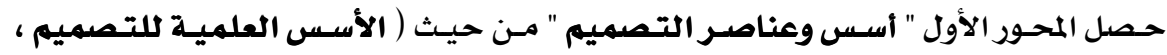

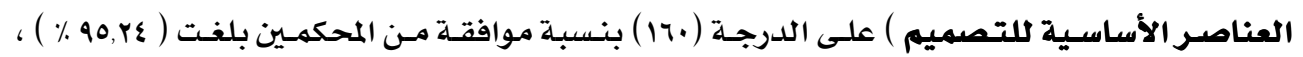

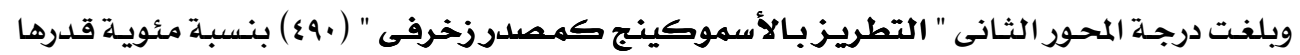

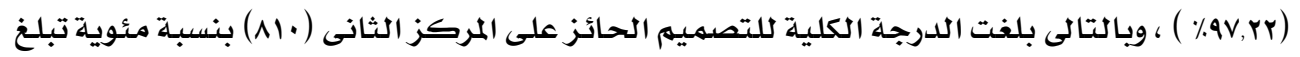

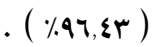
• أن التقديرات الكلية بالنسبة للتصميم الحائز على المركز الثالث (ه) :

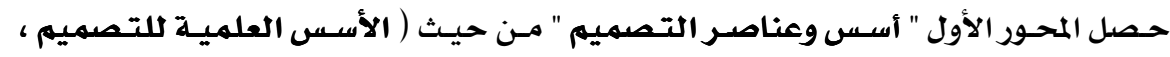

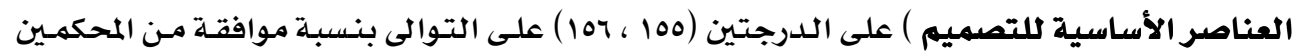

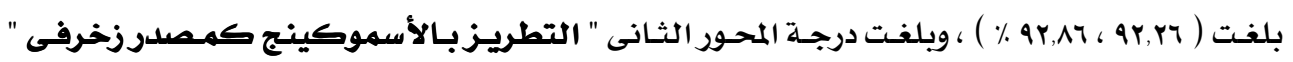




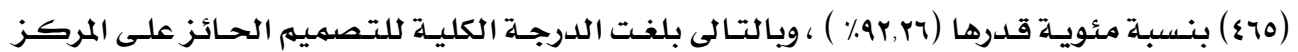

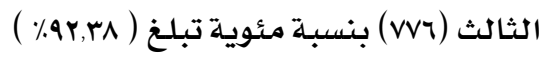
• أن التقديرات الكلية بالنسبة للتصميم الحائز على المركز الرابع (ه) :

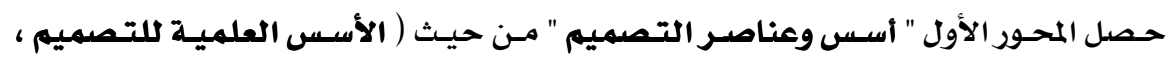

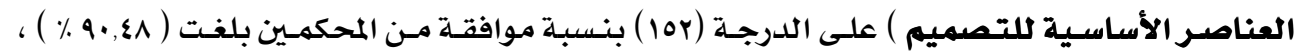

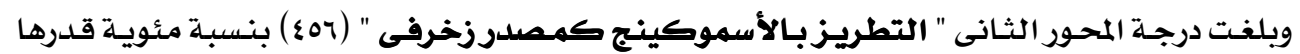

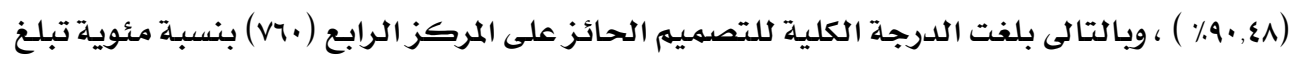
.$(\%,, \Sigma \Lambda)$

جدول ( r ) تحليل التباين لدراسة معنوية الفروق بين الدرجة الكلية للتصميمات الأربعة المنفذة قيد البحث

\begin{tabular}{|c|c|c|c|c|c|c|}
\hline مستوى الدلالة & قيمة " ف" & متوسط مجموع المربعات & درجة الحرية & مجموع المربعات & مصدر التبايز & التصميمات \\
\hline$\cdot, \cdots$ & *rYo, rEA & $\begin{array}{l}\text { Tr, YAT } \\
\text { •, ITE }\end{array}$ & $r$ & $\begin{array}{l}|9|, r 0 . \\
1 \cdot, r \cdot \cdot\end{array}$ & |دين المجموعات & 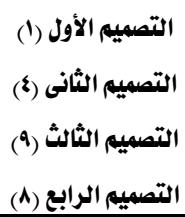 \\
\hline
\end{tabular}

(** * دال عند مستوى معنوية ( 1 (., )

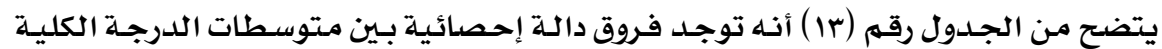

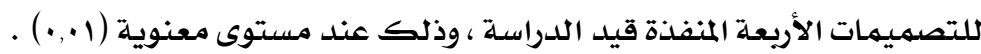

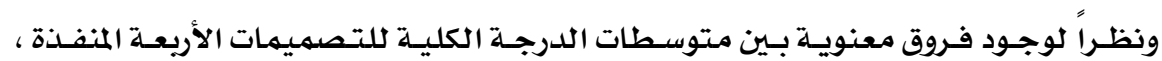

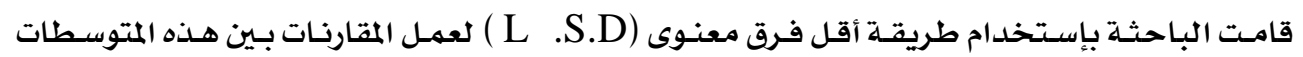

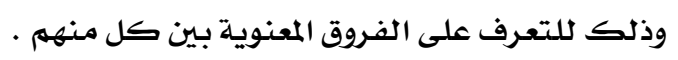

جدول (ع ا) أقل فرق معنوي بين متوسط الدرجة الكلية للتصميمات المنفذة قيد الدراسة

\begin{tabular}{|c|c|c|c|c|c|c|}
\hline الرابع (^) & الثالث (9) & الثانى (₹) & الأول (1) & الخطأ المعيارى & المتوسط الحسابى & التصميمات المنفذة \\
\hline & & & - & $\cdot, 117$ & $\varepsilon r, \cdots$ & التصميه الأول (1) \\
\hline & & - & $*_{1}, 0 .$. & $\cdot, 117$ & $\varepsilon \cdot, 0 .$. & التصميي الثانى (₹) \\
\hline & - & $*_{1}, \mathrm{r} \cdot \cdot$ & $* \mu, r . \cdot$ & $\cdot, 117$ & $r \Lambda, \Lambda \cdots$ & التصميم الثالث (9) \\
\hline- & $*_{\bullet, \Lambda \cdot \cdot}$ & $*_{r}, 0 .$. & $*_{\xi}, \cdots$ & $\cdot, 117$ & $r \wedge, \cdots$ & التصميه الرابع (^) \\
\hline
\end{tabular}

$$
\text { يتضح من جدول (ع ال ) مـا يلى : مستوى معنوية ( . ) ) }
$$

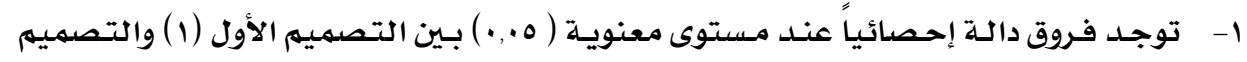

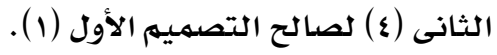




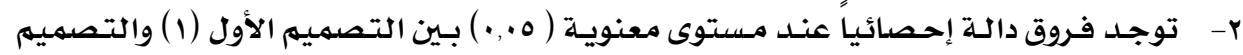

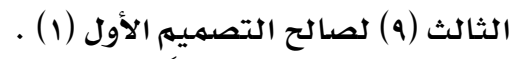

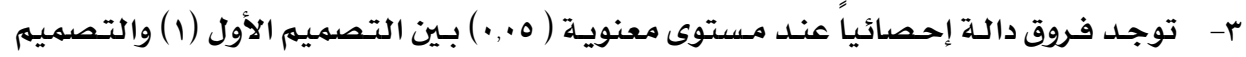

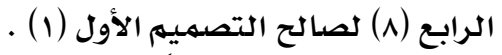

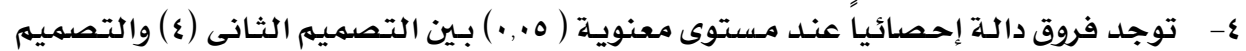

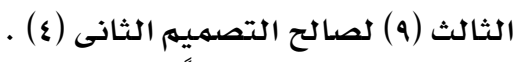

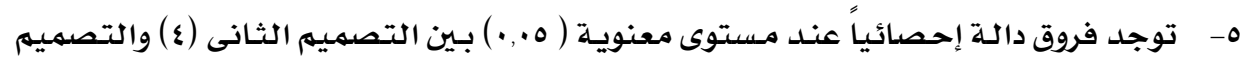

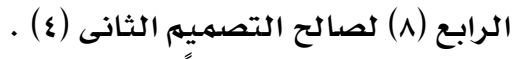

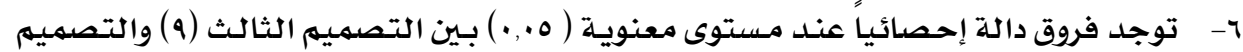

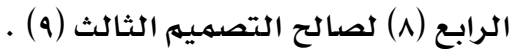

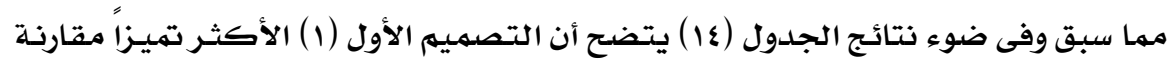

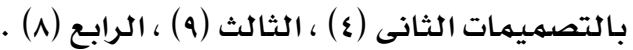

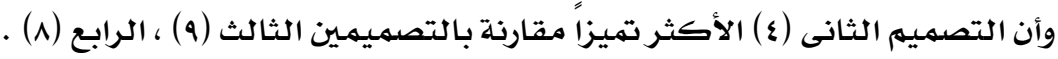

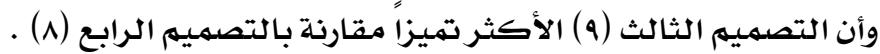

ويوضح شكل (v) المتوسط الحسابى للتصميمات الأربعة المختارة قيد الدراسـة

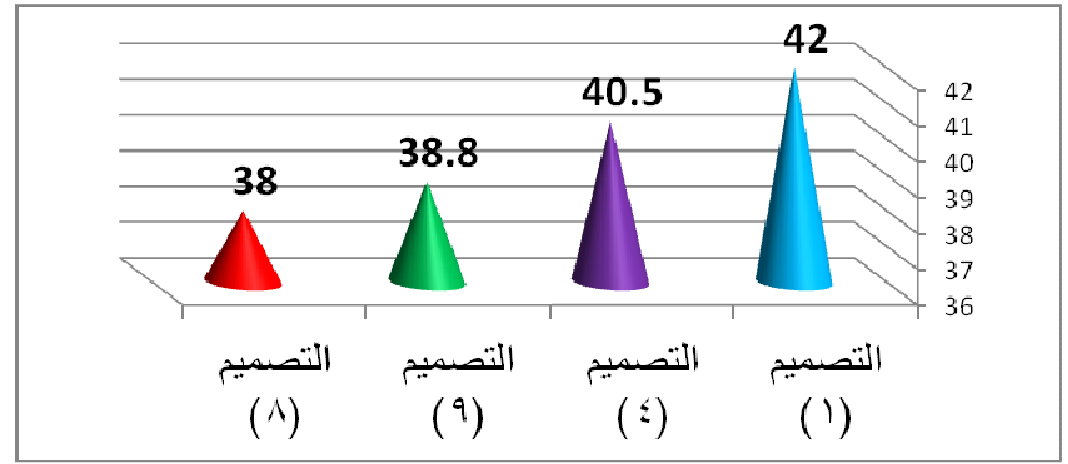

شكل (v) ترتيب التصميمات المختارة وفقاً للمتوسط الحسابى

\section{المراجع :}

ا. إلهام نفيس سفيان : " قابلية توظيف الخط العربي كخاصية فنيـة وكمـدخل لإثراء جماليـات ملابس

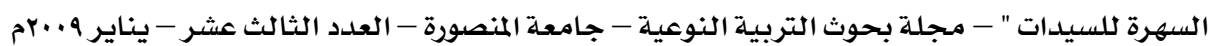

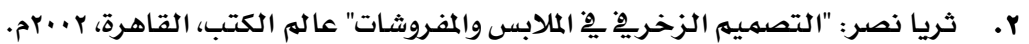

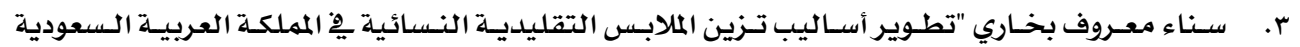

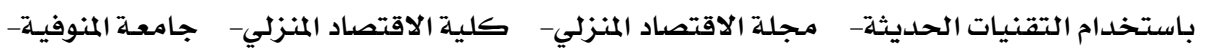

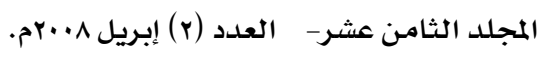




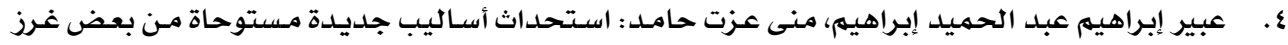

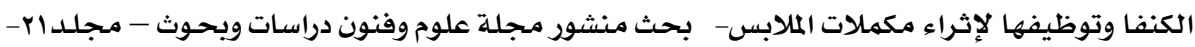

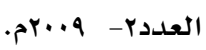

ع عصمت عبد المجيد حسن : " اللون كوسيط ابداعي فني للاتجاهات المعاصرة يِّ تصميم اقمشة السيدات

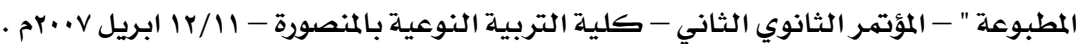
T. فاطمة محمد حسن ، ايناس عبد العزيز علي : " دراسـة تحليليـة لمجموعة غرز الاسموكينـج وتوظيفها فِ

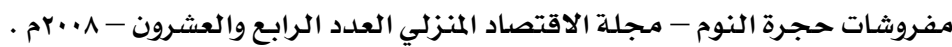

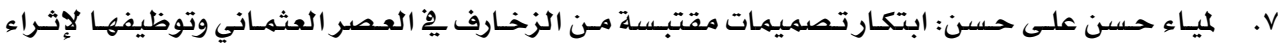

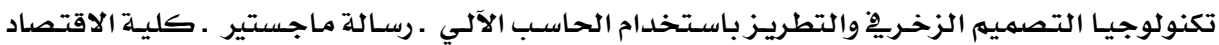

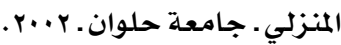

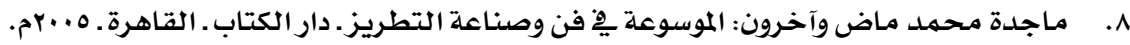

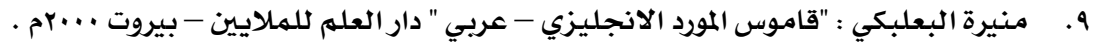

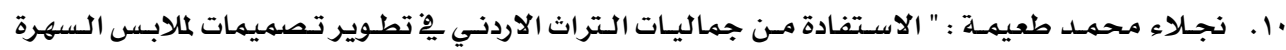
باستخدام اسـاليب التطريز المتطورة "- بحث منشور - المؤتهر السنوي العربي الخامس - كليـة التربيـة

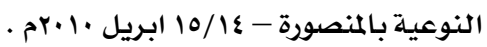
ا . هالة سليمان السيد سليمان : " التركيب النسسجي وتاثيره علسي بعض الاسـاليب الزخرفيـة لفـن التطريـز

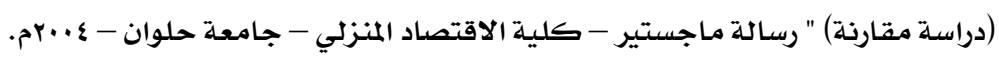
rا . هالة سليمان السيد سليمان : " اثر التطريز باسلوب الاسمـوكينج علـي الخصائص الوظيفيـة والجماليـة

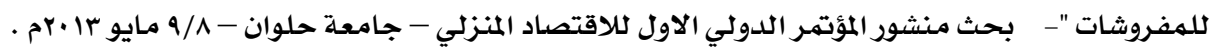




\section{Aesthetic Vision to Enrich The Ladies Clothing by Using Style Embroidery Smocking}

\section{Abstract}

Given the importance of clothing in all of our lives, it is essential to develop garment industry through integration of new traits into the product clothing to get him to the highest possible quality simple economic cost, and hand embroidery global art of the oldest works of art known to man, and began the beginning of human the same, as the first weaving done by Eve was a fig leaf which was the first clothing wears. And witness the history of the art of embroidery great attention throughout the ages, and includes human history around the world prepare boundless textile embroidered pieces.

Given the importance of hand embroidery on clothes, for fear it from extinction as a result of the spread of embroidery and automatic as it represents the hand embroidery of the beauty and values of heritage, where multiple and diverse hand embroidery techniques vary with each of these methods depends on several important factors, including user and threaded fabric and design to be decorated and each design is different the other in the user embroidery style.

So it went the researcher to use a new and innovative method of hand embroidery techniques embroidery smoking which is to enrich women's clothing, where research aims at enriching women's clothing using the aesthetics of style embroidery smoking and bring new creative entries. 